\title{
Što vrtić ima s tim? Pristup ranom i predškolskom odgoju i obrazovanju i reprodukcija društvenih nejednakosti u redovnom školovanju: analiza podataka PISA i TIMSS istraživanja
}

DOI: $10.5613 /$ rzs.49.1.1

UDK: 316.344

373.2

Izvorni znanstveni rad Primljeno: 19. 10. 2018.

Teo MATKOVIĆ

Zagreb, Hrvatska

teo.matkovic@gmail.com

Ivana DOBROTIĆ

Studijski centar socijalnog rada, Pravni fakultet Sveučilišta u Zagrebu, Hrvatska ivana.dobrotic@pravo.hr (autorica zadužena za korespondenciju)

Jelena BARAN

Zagreb, Hrvatska

baranjelena@gmail.com

\section{SAŽETAK}

Brojna istraživanja upućuju na važnost ranoga i predškolskog odgoja i obrazovanja (RPOO) za razvoj kognitivnih vještina te njihovu pripremu za školu, pri čemu je učinak RPOO-a, po pravilu, snažniji kod djece iz obitelji nižega socioekonomskog statusa (SES). Empirijske analize o društvenim nejednakostima u pristupu obrazovanju i školskom uspjehu u Hrvatskoj dominantno su se orijentirale na kasnije stadije školovanja, dok područje RPOO-a ostaje nepoznanicom. Cilj ovog rada bio je utvrditi obrasce povezanosti između pohađanja RPOO-a te kognitivnih postignuća u dobi od 10 i 15 godina u Hrvatskoj. Konkretnije, korištenjem podataka prikupljenih za Hrvatsku u okviru više ciklusa PISA i TIMSS istraživanja (2009.-2015.) ispitivalo se postoji li veza između pohađanja RPOO-a i kasnijih kognitivnih vještina iz područja matematike, čitanja i prirodoslovlja (opći doprinos) te razlikuje li se taj učinak s obzirom na SES roditelja (kompenzacijski učinak). Analiza nije poduprla hipotezu o kompenzacijskom učinku, ali je u većini slučajeva utvrđen određeni opći doprinos dugotrajnijeg pohađanja RPOO-a kognitivnim postignućima učenika od petine do desetine raspona jedne "razine znanja" u TIMSS i PISA testovima, a koji se ne može objasniti obrazovanjem ili zanimanjem roditelja, migracijskim podrijetlom, sastavom kućanstva ili obilježjima lokalne sredine. Promatrano u okviru obilježja hrvatskog sustava RPOO-a i ustanovljene velike 
nejednakosti u učestalosti i trajanju pohađanja programa s obzirom na SES roditelja, rad dodatno ukazuje na mehanizam efektivnog održavanja nejednakosti u obrazovanju u Hrvatskoj, koji daljnja ekspanzija RPOO-a može umanjiti.

Ključne riječi: rani i predškolski odgoj i obrazovanje, PISA, TIMSS, reprodukcija društvenih nejednakosti, kognitivna postignuća

\section{UVOD}

Rastući interes za sustav ranoga i predškolskog odgoja i obrazovanja (RPOO) potaknut je, između ostaloga, istraživanjima koja su pokazala važnost RPOO-a za razvoj kognitivnih i društvenih vještina kod djece te njihovu pripremu za školu (Neuman, 2005). Stoga brojne europske zemlje rastuću važnost pridaju upravo reformama na tom području (vidjeti npr. u Dobrotić, Matković i Menger, 2018), koje vide ključnima s aspekta društvenog ulaganja u smjeru pozitivnih obrazovnih ishoda kod djece, ali i sudjelovanja roditelja na tržištu rada. RPOO je osobito važan za djecu iz obitelji nižega socioekonomskog statusa (SES). Naime, SES obitelji bitno određuje materijalne, ljudske i društvene resurse kojima obitelj raspolaže i koje može uložiti u djetetov razvoj (Haveman i Wolfe, 1995; Brooks-Gunn i Duncan, 1997; Bradley i Corwyn, 2002; Conger i Donnellan, 2007), a koji imaju veliku ulogu u reprodukciji društvenog statusa (pregled u Breen i Jonsson, 2005). Jaz u školskom postignuću, prisutan već pri polasku u školu, vremenom se povećava. Stoga autori upozoravaju da i male razlike u uspjehu na početku školovanja mogu biti prediktori dugoročne prednosti (Entwisle, Alexander i Steffel Olson, 2005). U tom pogledu upravo kvalitetni RPOO može imati ključnu ulogu pri izjednačavanju životnih šansi (npr. Penn, 2009; Antulić Majcen i Pribela-Hodap, 2017).

Dosadašnje su se empirijske analize o društvenim nejednakostima u pristupu obrazovanju i školskom uspjehu u Hrvatskoj dominantno orijentirale na kasnije stadije školovanja (Gregurović i Kuti, 2010; Babarović, Burušić i Šakić, 2009; Jokić i Ristić Dedić, 2010; Matković, 2010; Matković, Tomić i Vehovec, 2010; Puzić, Gregurović i Košutić, 2016, 2018). Nejednakosti u pristupu RPOO-u, kao i njegov učinak na polaznike u Hrvatskoj nepoznati su, s iznimkom nekolicine starijih istraživanja na malim uzorcima (Duran, 1976; Jurčević-Lozančić, 1996). Cilj je ovog rada stoga ispitati postoji li u hrvatskom kontekstu veza između pohađanja RPOO-a i kasnijih kognitivnih vještina u vidu postignuća iz područja matematičke, čitalačke i prirodoslovne pismenosti te razlikuje li se taj učinak s obzirom na SES roditelja. Provjerit će se sukladnost rezultata s teorijski izvedenim hipotezama o općenitom doprinosu te kompenzacijskom učinku pohađanja RPOO-a. Pritom ćemo inovativno primijeniti retrospektivne podatke dostupne za Hrvatsku, prikupljene između 2009. i 2015. godine u okviru pet PISA i TIMSS istraživanja. S obzirom na činjenicu 
da su odgojno-obrazovni sustavi duboko (vrijednosno) ukorijenjeni u specifično povijesno i institucionalno nasljeđe pojedine zemlje (usp. Scheiwe i Willekens, 2009), koje uvelike utječe na percepciju primjerene brige za djecu najmlađe dobi, istraživanja su učinaka RPOO-a kontekstualno vrlo osjetljiva te se u svrhu informiranog i na dokazima temeljenog razvoja djelotvornih politika i programa RPOO-a ističe nužnost provođenja analiza u različitim kontekstima (Penn, 2009). Analize koje uzimaju u obzir specifičan hrvatski kontekst stoga predstavljaju nužnost za daljnji razvoj politika i programa RPOO-a u Hrvatskoj kao mogućeg te djelotvornog mehanizma smanjenja društvenih nejednakosti.

\section{DOPRINOS RPOO-A RAZVOJU (NE)KOGNITIVNIH VJEŠTINA KOD DJECE I DRUŠTVENOJ MOBILNOSTI}

SES obitelji najčešće se razmatra kroz prihode obitelji, obrazovanost roditelja i položaj roditelja u zanimanju. Istraživanja svakog od spomenutih aspekata SES-a pokazuju pozitivnu povezanost između višeg SES-a i uspješnosti djeteta u školi u smislu boljih ocjena, boljih rezultata na testovima znanja i vještina te višega dostignutog stupnja obrazovanja. ${ }^{1}$ Nalazi su konzistentni, kako u SAD-u i zapadnoeuropskim državama (npr. Wardsworth, 1986; Duncan, Brooks-Gun i Kato Klebanov, 1994; Haveman i Wolfe, 1995; Brooks-Gunn i Duncan, 1997; Smith, Brooks-Gunn i Kato Klebanov, 1997; McLoyd, 1998; Bradley i Corwyn, 2002; Entwisle, Alexander i Steffel Olson, 2005; Conger i Donnellan, 2007; Ermisch, 2008), tako i u postsocijalističkim državama (npr. lanelli, 2002; Kogan, Gebel i Noelke, 2012; Bodovski, Kotok i Henck, 2014) te Hrvatskoj (Babarović, Burušić i Šakić, 2009; Gregurović i Kuti, 2010; Jokić i Ristić Dedić, 2010; Matković, 2010; Matković, Tomić i Vehovec, 2010; Puzić, Gregurović i Košutić, 2016, 2018).

Postoji nekoliko mehanizama putem kojih programi RPOO-a poboljšavaju školski uspjeh djece (Reynolds, Ou i Topitzes, 2014; Čudina Obradović, 1994): kognitivna prednost koju dijete stekne u dječjem vrtiću u vidu bolje spremnosti za školu, što ga štiti od upadanja u začarani krug nakon početnog neuspjeha; rad s roditeljima i utjecaj na njihova ponašanja, stavove i očekivanja te veće sudjelovanje u

Duncan, Brooks-Gunn i Kato Klebanov (1994) nalaze da je kvaliteta obiteljskog okruženja odgovorna za trećinu efekta doprinosa obitelji kvocijentu inteligencije djeteta u dobi od pet godina, dok Brooks-Gunn i Duncan (1997) prikazuju studije prema kojima je riječ o polovini tog efekta. Manjak stimulativnih iskustava u obitelji nepovoljno djeluje na kognitivni razvoj i smanjuje mogućnosti djeteta da "profitira" od pohađanja škole (Bradley i Corwyn, 2002). Također, sukladno teoriji o važnosti kulturnog kapitala učitelji (i sami pripadnici više klase) će procijeniti sposobnosti i inteligenciju djece prema njihovu ponašanju pa će očekivanja te pažnja i trud koji će ulagati u njihov uspjeh ovisiti o toj procjeni, što vodi stvarnom uspjehu pozitivno procijenjene djece (Bourdieu, 1977; analiza za Hrvatsku: Puzić, Gregurović i Košutić, 2016). 
obrazovanju svoje djece; motivacijska prednost u smislu ustrajnosti, samopouzdanja, planiranja, orijentacije na zadatak i slično; prednost u smislu usvojenosti društvenih pravila, samodiscipline, sposobnosti slaganja s drugima. Istraživanja o učincima pohađanja RPOO-a na školski uspjeh započela su s američkim eksperimentalnim studijama kompenzacijskih programa koje su pokazale da je uključivanjem djece u RPOO moguće poboljšati njihovu spremnost za učenje i školovanje, kao i životne ishode, putem unapređenja (ne)kognitivnih vještina (Karoly i dr., 1998; Melhuish, 2004; Morrissey i Warner, 2007; Heckman i Masterov, 2007). S obzirom na to da je riječ o ciljanim programima za djecu u ozbiljnim socijalnim i zdravstvenim razvojnim rizicima, spomenute studije nisu se mogle generalizirati na učinke pohađanja RPOO-a na općoj populaciji djece, napose u europskom kontekstu, koji često karakterizira tendencija k univerzalnim programima te drukčiji socijalni režimi (Penn, 2009).

Većina novijih istraživanja na općoj populaciji u američkim i zapadnoeuropskim zemljama upućuje na povezanost pohađanja RPOO-a i kognitivnog razvoja djeteta koji je mjeren putem standardiziranih testova matematike i jezika, ocjena u školi, stope ponavljanja razreda, završavanja srednje škole i slično (Andersson, 1992; Lamb, 1996; Broberg i dr., 1997; NICHD ECCRN, 2000, 2001; NICHD ECCRN i Duncan, 2003; Bridges i dr., 2004; Magnuson i dr., 2004; Magnuson, Ruhm i Waldfogel, 2004; Melhuish, 2004; Loeb i dr., 2007; Pianta i dr., 2009; Camilli i dr., 2010; Sylva i dr., 2011; za Hrvatsku: Duran, 1976; za detaljan pregled europskih longitudinalnih istraživanja usp. European Commission, 2014). Tek manji broj ranijih istraživanja ne nalazi takvu povezanost (npr. pregled u Belsky, 1988). Longitudinalna istraživanja koja su gledala dugoročnost učinaka ne pružaju jednoznačne rezultate. Neka upućuju na značajne razlike u školskom uspjehu i u starijoj dobi djece (Andersson, 1992; Sylva i dr., 2008; Camili i dr., 2010; OECD, 2010; za zemlje Europske unije pregled u European Commission, 2014), a druga na izostanak dugoročnijeg učinka (Field, 1991; Barnett, 1995; Olsen, 1999; Gilliam i Zigler, 2001; NICHD ECCRN i Duncan, 2003; Melhuish, 2004; Entwisle i dr., 2005; NICHD ECCRN, 2005; Pianta i dr., 2009; Lowe Vandell i dr., 2010). Treba naglasiti da se većina istraživanja bavila pohađanjem vrtićkih programa, dok su rjeđa istraživanja koja se bave ishodima djece koja su pohađala jasličke programe i ona ponajprije istražuju socioemocionalni razvoj i ponašanje djece (za istraživanja koja pokazuju pozitivan učinak pohađanja jaslica na kognitivni razvoj djece vidjeti npr. Andersson, 1989, 1992; NICHD ECCRN, 2000; Sylva i dr., 2004; Belsky i dr., 2007; Felfe i Lalive, 2010).

SES obitelji dosljedno se pokazuje značajnim moderatorom učinaka u kognitivnom području proizišlih iz pohađanja RPOO-a. Pozitivan doprinos pohađanja RPOO-a školskom uspjehu izraženiji je kod djece iz obitelji nižeg SES-a (Belsky, 
1988; Lamb, 1996; Bridges i dr., 2004; Magnuson i dr., 2004; Melhuish, 2004; Pianta i dr., 2009; European Commission, 2014). Pojedina su istraživanja uz tako ustanovljen pozitivan doprinos pohađanja RPOO-a školskom uspjehu djece iz obitelji nižeg SES-a pokazala i to da pohađanje RPOO-a nije imalo učinka ili pak je negativno djelovalo na školski uspjeh kod djece iz boljestojećih obitelji (Desai, Chase-Lansdale i Michael, 1989; O'Brien Caughy, DiPietro i Strobino, 1994; Olsen, 1999; Sylva i dr., 2011; Havnes i Mogstad, 2012). Dominantna interpretacija (O’Brien Caughy, DiPietro i Strobino 1994; Lamb, 1996; Karoly i dr., 1998; Melhuish, 2004; Morrissey i Warner, 2007; Heckman i Masterov, 2007) ističe da bi za pozitivan učinak pohađanja RPOO-a ti programi trebali biti kvalitetni te da bi kvaliteta RPOO-a trebala nadilaziti kvalitetu okruženja u obitelji. Tada bi odgojno-obrazovne funkcije RPOO-a smanjivale jaz u kognitivnim vještinama, a time i kasnijim obrazovnim postignućima djece koja in pohađaju. Stoga je iznimno važan i institucionalni kontekst koji definira kako pokazatelje kvalitete, tako i otvorenost sustava djeci iz obitelji različitog SES-a. Primjerice, dok su u Francuskoj i Belgiji programi RPOO-a razvijani sa svrhom obrazovanja djece i stoga imaju gotovo univerzalnu obuhvaćenost djece programima, u Velikoj Britaniji, Irskoj i SAD-u predškolske se ustanove razvijaju ponajprije radi brige za djecu zaposlenih roditelja te je obuhvaćenost djece predškolskim programima u tim zemljama niska i cilja djecu zaposlenih roditelja (Scheiwe i Willekens, 2009). S obzirom na specifičnosti institucionalnog te kontekstualnog okruženja, ne iznenađuje da se procjene mogućnosti RPOO-a za smanjenje jaza u predakademskim vještinama pri polasku u školu između djece iz obitelji višeg i nižeg SES-a kreću od 1 do 3,6\% (Olsen, 1999), više od 5\% (Pianta i dr., 2009), pa sve do 50\% (Bridges i dr., 2004; Camilli i dr., 2010) postojećeg jaza.

\section{CILJ RADA}

Cilj je ovog rada utvrditi postojanje i obrasce povezanosti između pohađanja RPOO-a te kognitivnih postignuća u dobi od 10 i 15 godina u Hrvatskoj, a na temelju nacionalnoreprezentativnih podataka hrvatskih dionica pet međunarodnih istraživanja. Zaključci prethodno prikazanih istraživanja, u kontekstu relativno povoljnih strukturnih pokazatelja kvalitete RPOO-a u Hrvatskoj (European Commission, ECEA i Eurydice, 2016) vode postavljanju dviju hipoteza. Prve, o općenitom doprinosu pohađanja RPOO-a na kasnija postignuća učenika, prema kojoj se na RPOO može gledati kao na univerzalni obrazovni resurs koji povećava kognitivne sposobnosti djece (npr. NICHD ECCRN, 2000, 2001; NICHD ECCRN i Duncan, 2003; Bridge i dr., 2004; Magnuson i dr., 2004; Melhuish, 2004; Loeb i dr., 2007; Pianta i dr., 2009; Camilli i dr., 2010; OECD, 2010). Druge, o kompenzacijskom 
učinku, prema kojoj će doprinos pohađanja RPOO-a biti snažniji kod djece iz obitelji nižeg SES-a. Naime, istraživanja u hrvatskom kontekstu pokazuju kako roditelji nižeg SES-a sudjeluju u manje razvojno-poticajnih i podržavajućih roditeljskih postupaka i manje su im dostupni rekreativni i obrazovni sadržaji za djecu, kao i zdravstvena skrb, usluge za roditelje te neformalna podrška (Pećnik, 2013; Šućur i dr., 2015). Upravo je obrazovanje roditelja komponenta SES-a koja omogućuje poticajnije obrazovno okružje za dijete bilo kroz kulturni kapital i habitus (uključuje i roditeljsko poznavanje obrazovnog sustava), ljudski kapital (opća znanja i vještine relevantna za školski uspjeh) ili obrazovna očekivanja i strategije (npr. Stocké, 2007). Stoga očekujemo kako će učinak pohađanja RPOO-a biti izraženiji s nižim stupnjem obrazovanja roditelja djece polaznika, odnosno nižom razinom njihova društvenoga, kulturnog i ljudskog kapitala. Upravo bi ta djeca trebala imati posebne koristi od pohađanja RPOO-a s obzirom na to da su u okviru odgojno-obrazovne funkcije RPOO-a češće izložena razvojno-poticajnijem okruženju od onoga u okviru vlastite obitelji (Karoly i dr., 1998; Melhuish, 2004; Morrissey i Warner, 2007; Heckman i Masterov, 2007).

\section{METODOLOGIJA}

U svrhu provjere hipoteza u hrvatskom kontekstu koristit ćemo se podacima više ciklusa dvaju međunarodnih istraživanja učeničkih postignuća: Međunarodne procjene znanja i vještina učenika (The Programme for International Student Assessment - PISA) koju provodi OECD i Međunarodnog istraživanja trendova u znanju matematike i prirodoslovlja (Trends in International Mathematics and Science Study - TIMSS) što ga organizira IEA (International Association for the Evaluation of Educational Achievement). U svrhu unapređenja obrazovnih politika, oba se istraživanja periodično provode u više od 40 država te u svakoj uključuju više od 4000 učenika. Na testovima se procjenjuje pismenost, za PISA studije operacionalizirana kao "sposobnost učenika da primijene znanja i vještine iz ključnih predmetnih područja i da analiziraju, logički zaključuju i djelotvorno komuniciraju kod postavljanja, rješavanja i interpretiranja problema u različitim situacijama" (Braš Roth i dr., 2007: 3). Osim testa znanja koji ispunjavaju učenici, učitelji i roditelji ispunjavaju kontekstualne upitnike o obilježjima obrazovnog sustava i tijeku školovanja djeteta, uključujući i pitanje je li dijete pohađalo RPOO, što ta istraživanja čini relevantnim izvorom podataka za ovaj rad. Pregled podataka o godinama provođenja istraživanja, veličini uzoraka i razdoblju pohađanja RPOO-a prikazan je u Tablici 1. 
Tablica 1. Sumarne informacije o uzorku te kriterijskim, prediktorskim i kontrolnim varijablama PISA i TIMSS istraživanja provedenih u Hrvatskoj između 2009. i 2015.

\begin{tabular}{|c|c|c|c|c|c|c|c|}
\hline $\begin{array}{c}\text { godina } \\
\text { testiranja }\end{array}$ & istraživanje & $\mathrm{N}$ & $\begin{array}{l}\text { razdoblje } \\
\text { pohađanja } \\
\text { RPOO-a }\end{array}$ & $\begin{array}{c}\text { dob prilikom } \\
\text { testiranja }\end{array}$ & $\begin{array}{l}\text { program } \\
\text { jaslica/ } \\
\text { vrtića, } \\
\text { trajanje* }\end{array}$ & $\begin{array}{c}\text { iskazi o } \\
\text { pohađanju } \\
\text { daje }\end{array}$ & $\begin{array}{c}\text { kontrole (osim } \\
\text { obrazovanja } \\
\text { roditelja)* }\end{array}$ \\
\hline 2009. & PISA & 4994 & 1995.-2000. & 15 godina & $\mathrm{J} / \mathrm{V}$ & $\begin{array}{l}\text { Učenik } \\
\text { (osim J) }\end{array}$ & ZI, M, K \\
\hline 2012. & PISA & 4750 & 1998.-2003. & 15 godina & V & Učenik & ZI, M, K \\
\hline 2015. & PISA & 5809 & 2001.-2006. & 15 godina & $\mathrm{J} / \mathrm{V} / \mathrm{T}$ & Roditelj & ZI, M, K \\
\hline 2011. & TIMSS & 4584 & 2002.-2007. & $\begin{array}{c}\text { približno } 10 \\
\text { godina } \\
\text { (4. razred) }\end{array}$ & $\mathrm{V} / \mathrm{T}$ & Roditelj & $Z$, Š \\
\hline 2015. & TIMSS & 4164 & 2006.-2011. & $\begin{array}{c}\text { približno } 10 \\
\text { godina } \\
(4 . \text { razred })\end{array}$ & $\mathrm{J} / \mathrm{V} / \mathrm{T}$ & Roditelj & Z, Š, M \\
\hline
\end{tabular}

* J: program jaslica; V: program vrtića; T: trajanje pohađanja programa; Z: skupina zanimanja roditelja; ZI: ISEI skor roditelja; M: migrantski status i dob imigracije; K: karakteristike kućanstva (samohrani roditelj i višegeneracijsko kućanstvo); Š: karakteristike škole (vrsta naselja i udio djece iz obitelji niskoga SES).

Korišteni skupovi podataka na razini pojedinaca (mikropodaci) za sve cikluse istraživanja i zemlje u otvorenom su pristupu dostupni na poslužiteljima OECD-a i IEA-a te omogućuju spajanje procjene postignuća s učeničkim, roditeljskim, nastavničkim i ravnateljskim kontekstualnim upitnicima. $U$ ovom smo radu analizirali podatke svih pet ciklusa dostupnih u 2018. godini (PISA-2009, PISA-2012, PISA-2015 te TIMSS-2011 i TIMSS-2015) u kojima su sudjelovali učenici iz Republike Hrvatske.

\subsection{Mjerni instrumenti}

Kao kriterijske varijable kognitivnog postignuća koristili smo procjenu razine matematičke, prirodoslovne i čitalačke pismenosti (potonje samo na temelju PISA istraživanja) učenika u dobi od deset (TIMSS) odnosno petnaest (PISA) godina. Kako se ovim istraživanjima analizirao širok raspon tema u svakom području procjene, operacionaliziran kroz veliki broj zadataka (koji se dijelom mijenjaju između ciklusa), pojedini učenik rješavao je tek njihov manji podskup. Tako su TIMSS-2011 i TIMSS-2015 sadržavali 14 blokova pitanja iz svakog područja i 14 varijanti ispitne knjižice (Mullis i Martin, 2013), dok je PISA-2015 provedena s pomoću računala i 
svakoj je pojedinoj čestici pristupilo $11-12 \%$ sudionika. Takav dizajn ne omogućuje izravnu usporedbu uspjeha pojedinačnih sudionika, ali dopušta procjenu postignuća na razini populacije i skupina unutar nje. Temeljem uspjeha na zadacima kojima su sudionici pristupili, procedurom koja uključuje kalibraciju čestica i primjenu latentnoga regresijskog modela, za svakog se sudionika procjenjuje skup više (u ovim istraživanjima 5-10) tzv. vjerojatnih vrijednosti (plausible values) postignuća u svakom području mjerenja (više u Wu, 2005; poglavlja 4 i 13 u Martin, Mullis i Hooper, 2016; poglavlja 9 i 12 u OECD, 2017a). Te vrijednosti, izražene bodovno za svako područje (na razini sudionika najčešće između 300 i 700 bodova) služe kao temelj svih PISA i TIMSS analiza i publikacija, pa tako i analiza u ovom radu (npr., prosječne vrijednosti s obzirom na razinu obrazovanja roditelja u Tablici P2 u Prilozima). Razlika od 30 bodova okvirno odgovara jednoj godini školovanja. Također, temeljem prosjeka vjerojatnih vrijednosti polaznici se kategoriziraju u razine znanja kojima vladaju (proficiency levels - PISA) odnosno međunarodna mjerila postignuća (International Benchmarks - TIMSS), pri čemu raspon jedne razine u oba istraživanja iznosi otprilike 75 bodova. Prag četiri razine u TIMSS-2015 400 je bodova (nisko mjerilo), 475 (srednje), 550 (visoko) te 625 (napredno), dok se uspjeh na PISA testu kategorizira u sedam razina znanja (npr. prirodoslovlje u PISA-2015: 260 /1b/, 335 /1a/, 410 /2/, 484 /3/, 559 /4/, 633 /5/ i 708 /6/).

Skupovi istraživačkih mikropodataka za sve su sudionike sadržavali pet (TIMSS-2011, TIMSS-2015; PISA-2009, PISA-2012) odnosno deset (PISA-2015) vjerojatnih vrijednosti u svakom području procjene. Kako bi varijanca postignuća imputiranih kroz vjerojatne vrijednosti bila adekvatno procijenjena, za analizu je uz prikladna utežanja i parametrizaciju korišten PV modul za statistički program Stata.

Prediktorske varijable odnose se na pohađanje RPOO-a (Tablica 1). Kontekstualni upitnici svih korištenih istraživanja omogućili su formiranje temeljnoga dihotomnog pokazatelja operacionaliziranog kao pohađanje RPOO-a više od godinu dana. Takav smo prag odredili s obzirom na važnost trajanja programa za vidljiviji učinak intervencije (Andersson, 1989, 1992; Broberg, 1997; pregled u Van Belle, 2016; za PISA usp. OECD 2017b), ali i stoga što su se iskazi o pohađanju kraćem od godinu dana u Hrvatskoj mogli temeljiti na pohađanju kratkog programa predškole. Pritom ćemo iskaze koji dolaze od roditelja (dakle TIMSS i PISA-2015) smatrati pouzdanijima. Naročito u PISA-2015 istraživanju, gdje su u kontekstualnom upitniku za roditelje eksplicitno razdvojena pitanja o pohađanju jasličkog programa, vrtićkog programa i programa predškole te je bilo moguće preciznije odrediti ovu varijablu kao pohađanje vrtićkih programa barem u jednoj godini. ${ }^{2}$ Druga je pre-

2 Ta se operacionalizacija razlikuje od one u PISA-2015 publikacijama (npr. OECD 2017b: 150-153) koje su se koristile informacijama iz učeničkoga kontekstualnog upitnika koji je primijenjen u svim zemljama te sadržava pitanja formulirana identično kao u ranijim ciklusima. Usporedbom iskaza 
diktorska varijabla pohađanje jasličkog programa, koju je bilo moguće ustanoviti iz odgovora roditelja u TIMSS-2015, PISA-2009 i PISA-2015 istraživanjima, s time da su u prva dva istraživanja roditelji eksplicitno pitani za pohađanje jasličkog programa, a iz detaljnijeg PISA-2015 upitnika kao polaznike jasličkog programa odredili smo samo djecu koja su bila korisnici RPOO-a ukoliko je za njih brinula osoba koje je stručno osposobljena, a usluga se provodila u specijaliziranoj ustanovi. Treće, u TIMSS-2011, TIMSS-2015 i PISA-2015 istraživanjima bilo je moguće aproksimirati trajanje pohađanja RPOO-a. U TIMSS istraživanjima korišten je iskaz roditelja o trajanju pohađanja (program predškole nije eksplicitno isključen), dok su u PISA2015 istraživanju pribrojene sve godine u kojima su roditelji iskazali da je dijete pohađalo program jaslica ili vrtića (ali ne i program predškole). ${ }^{3}$

Najviše obrazovanje roditelja je ključna kontrolna varijabla, čija je snažna veza s kriterijskom varijablom na ovim podacima dobro poznata (npr. Gregurović i Kuti, 2010; usp. Tablica P2 u Prilozima). S obzirom na visoku razinu kolinearnosti obrazovanja oca i majke uslijed obrazovne homogamije, obrazovanje roditelja smo operacionalizirali kao jednu varijablu "najviša postignuta razina obrazovanja (bilo kojeg od) roditelja". Ta je varijabla grupirana u pet kategorija s jasnom hijerarhijom, od kojih je svaka dostatno zastupljena u populaciji za pouzdanu procjenu učinka: "bez srednje škole”, "trogodišnja srednja škola", "četverogodišnja srednja škola ili gimnazija", "stručni studij" te "sveučilišni studij i više". ${ }^{4}$ S obzirom na rijetku pojavnost, u pripremi su podataka svi slučajevi obrazovanja nižeg od srednje škole svedeni u najnižu kategoriju ("bez srednje škole"), a magisteriji i doktorati agregirani su sa sveučilišnim studijem.

hrvatskih učenika i roditelja u PISA-2015 istraživanju vidljivo je da se oni razlikuju u $30 \%$ slučajeva - u $9 \%$ slučajeva roditelji tvrde da su djeca pohađala RPOO, a djeca se ne prisjećaju, dok u $21 \%$ slučajeva djeca tvrde da su pohađala vrtićki program, a roditelji ne, odnosno incidencija je bitno veća kod iskaza djece (70\%) nego roditelja (58\%). Dio razlike izgledno proizlazi iz činjenice da su se djeca često prisjećala programa predškole kao RPOO-a, jer kad se isključe djeca koja su izjavila da su uključena u RPOO sa šest godina, broj "lažnih pozitiva" i "lažnih negativa" postaje simetričan (12-13\%), no još uvijek se u četvrtini slučajeva iskazi roditelja i djece o pohađanju RPOO-a razlikuju. Detaljniju formulaciju postavljenih pitanja za roditelje i prisjećanje roditelja smatramo pouzdanijim izvorom informacija o pohađanju RPOO-a u PISA-2015 istraživanju.

3 Trajanje je u TIMMS analizama operacionalizirano strože nego u PISA-2015 publikacijama (npr. OECD, 2017b) u kojima je preuzeto iz kontekstualnog upitnika za učenike - kao razlika dobi u kojoj su krenuli u školu i dobi u kojoj su iskazali da su počeli pohađati program jaslica/vrtića (1-6). U PISA-2015 publikacijama operacionalizirano trajanje uključuje i program predškole te ne razmatra mogućnost prekida u pohađanju jaslica/vrtića.

$4 \quad$ Roditelji djece rođene između 1994. i 2005. godine u vrijeme kad su njihova djeca pohađala RPOO nisu mogli imati diplome prema bolonjskom programu (koje su studenti na razini prvostupnika počeli stjecati oko 2009). 
U oba TIMSS istraživanja informacije o obrazovanju prikupljane su u roditeljskom kontekstualnom upitniku, pri čemu u TIMSS-2011 istraživanju nije bilo moguće razlikovati trogodišnje od četverogodišnjega srednjeg obrazovanja. U PISA istraživanjima izazov predstavlja što se informacije o obrazovanju roditelja prikupljaju od učenika i to na sekvencijalni način koji nije uobičajen u Hrvatskoj. Učenici za svakog roditelja najprije unose je li završio trogodišnje strukovno, četverogodišnje srednje obrazovanje ili manje od toga, a potom mogu odabrati bilo koji broj (ili niti jedan) od četiriju navedenih oblika postsekundardnog obrazovanja (doktorat ili magisterij; diploma fakulteta ili akademije; dvogodišnja ili trogodišnja viša škola; stručno usavršavanje nakon završene srednje škole). S obzirom na problematičnu konstrukciju izvedene varijable obrazovanja roditelja uključene u skup mikropodataka koje konzorcij istraživačima stavlja na raspolaganje, za potrebe analiza u ovom radu kreirali smo "strogu" varijablu obrazovanja roditelja. Ona je izvedena tako da (i) ne uzima u obzir iskaze učenika o visokom obrazovanju roditelja ukoliko su prethodno unijeli kako su završili trogodišnje strukovno obrazovanje ili manje, (ii) ne uzima u obzir iskaze o stručnom postsekundarnom usavršavanju (budući da je ono najčešće neformalno) te (iii) pripisuje nižu razinu obrazovanja u slučajevima kad su učenici za obrazovanje roditelja označili i stručni i sveučilišni studij (u stvarnosti izrazito rijetka kombinacija). ${ }^{5}$ Takvom je korekcijom najviši stupanj obrazovanja roditelja revidiran naniže u 2015. za 1173 sudionika (20,5\% unosa), u 2012. za 878 (17,8\%), a u 2009. za 788 (16,1\%) (usp. Tablica P1 u Prilozima). I nakon te korekcije, iskazi o obrazovnoj strukturi roditelja izgledno su pristrani naviše (npr. $34 \%$ učenika s barem jednim viskoobrazovanim roditeljem u 2009. u odnosu na 23\% prema Anketi o radnoj snazi u razdoblju 2006.-2008; Matković, 2010).

Izravan učinak SES-a na postignuće dodatno je kontroliran kroz najvišu skupinu zanimanja roditelja (TIMSS) odnosno viši skor međunarodnoga socioekonomskog indeksa (International Socioeconomic Index - ISEI) zanimanja roditelja (PISA). ISEI

$5 \quad$ Ukoliko je učenik unio bilo koji od oblika postsekundarnog obrazovanja, najviši od njih bilježi se u izvedenoj varijabli (MISCED odnosno FISCED) koja se koristi u PISA publikacijama i nalazi pripremljena u analitičkom skupu mikropodataka. Pri generiranju te varijable za Hrvatsku u niti jednom PISA istraživanju unos učenika o visokom obrazovanju nije kontroliran s obzirom na iskaz o roditeljskom srednjem obrazovanju. Tako su, na primjer, u PISA-2015 učenici za 37\% očeva i $43 \%$ majki koji su završili trogodišnje strukovno obrazovanje ujedno iskazali da su završili visoko obrazovanje što je slijed koji je u teoriji bio moguć, ali u praksi iznimno rijedak. To ne vodi samo neuobičajeno visokoj procjeni strukture obrazovanja roditelja ( $53 \%$ učenika s barem jednim visokoobrazovanim roditeljem u 2015., 46\% u 2012. i 44\% u 2009), nego i upitnoj kriterijskoj valjanosti nekorigiranog konstrukta obrazovanja roditelja. Na primjer, primjenom priloženih varijabli roditeljskog obrazovanja u 2015. proizlazi kako $51 \%$ učenika trogodišnjih strukovnih škola ima barem jednoga visokoobrazovanog roditelja te kako roditelji sa stručnim studijem imaju za tri boda niži SES (iskazan kroz ISEI skor) od roditelja s četverogodišnjom srednjom školom, a njihova djeca za 22 boda slabiji prosječni uspjeh iz matematičke, čitalačke i prirodoslovne pismenosti (identičan $\mathrm{s}$ djecom roditelja s trogodišnjom strukovnom školom). 
skor je posebno koristan u ovu svrhu jer je generiran optimalnim skaliranjem tako da maksimizira neizravni učinak obrazovanja kroz zanimanje, a minimizira izravnu vezu obrazovanja i prihoda (Ganzeboom i Treiman, 1996). Stoga uključivanjem ISEI skora kao kovarijata minimaliziramo izravni ekonomski značaj obrazovanja roditelja. Usto, modeli su kontrolirani za učinak čimbenika koji su nerijetko povezani sa SES-om te utječu na karakter obiteljskog okruženja u kojem dijete odrasta: imigrantski status (generacija i dob doseljenja) (TIMSS-2015, PISA-2009-2015), jednoroditeljsko kućanstvo (PISA-2009, PISA-2012), život u višegeneracijskom kućanstvu s bakom ili djedom (PISA-2009, PISA-2012) te čuvanje od strane rođaka (PISA-2015). Također, kroz TIMSS istraživanja u upitniku za ravnatelje prikupljana je informacija o razini urbanizacije i udjelu učenika niskog SES-a u školi, koje su korištene kao kontrolne varijable širega socioekonomskog okruženja lokaliteta, $s$ obzirom na to da je pohađanje osnovnih škola ustrojeno prema teritorijalnom ključu, a područja (naselja, kvartovi) nadležnosti škola i vrtića uvelike se preklapaju.

Sudionici kod kojih nije bilo moguće utvrditi razinu obrazovanja niti jednog roditelja, kod kojih je nedostajala informacija o nekom od kovarijata ili nije bilo moguće spojiti roditeljski upitnik $s$ učeničkim ili ravnateljskim isključeni su iz analiza. Broj takvih isključivanja iznosio je 105 (PISA-2009), 62 (PISA-2012), 93 (PISA-2015), 170 (TIMSS-2011) i 116 (TIMSS-2015), odnosno 2-4\% ukupnog broja sudionika istraživanja, a koji nisu u velikoj mjeri odstupali od ostalih s obzirom na razinu postignuća ili pohađanja RPOO-a.

\subsection{Analitička strategija}

Temeljna analiza počiva na seriji OLS linearnih regresija na vjerojatnim vrijednostima svake vrste pismenosti u svih pet istraživanja. U početnom smo koraku koristili samo po jedan prediktor, odnosno usporedili postignuća na pojedinom testu svakog istraživanja između djece koja su pohađala RPOO te djece koja nisu pohađala RPOO. U drugom smo koraku u svrhu provjere prve hipoteze o općem doprinosu RPOO-a izolirali potencijalni učinak pohađanja RPOO-a nakon što su u regresijski model uključeni najviše postignuto obrazovanje roditelja i druge kontrolne varijable. U završnom smo koraku u svrhu provjere druge hipoteze o kompenzacijskom učinku pohađanja RPOO-a uključili interakcijski učinak pohađanja RPOO-a s obzirom na razinu obrazovanja roditelja. Zbog velikog broja specifikacija u rezultatima su prikazane tek procjene učinka prediktora (pohađanja RPOO-a) odnosno interakcije (pohađanja RPOO-a s obzirom na obrazovanje roditelja).

Uz temeljne modele korištene su dvije dodatne analize u svrhu provjere robusnosti nalaza. Prvo, s obzirom na velike regionalne razlike u obuhvaćenosti djece RPOO-om (Dobrotić, Matković i Menger, 2018), ali i na heterogenost lokaliteta 
u obrazovnoj strukturi stanovništva i razini razvijenosti te dostupnosti RPOO-a moguće je da ustanovljena veza dijelom proizlazi iz karakteristika lokalne zajednice koje nisu uključene u temeljni regresijski model (u kojem se nalaze tek razina urbaniteta i udjel učenika slabog SES-a prikupljeni kroz TIMSS ravnateljski upitnik). Tu je neopaženu heterogenost ipak moguće izolirati kontrolirajući za doprinos lokaliteta operacionaliziranog kao dummy varijabla za svaku pojedinu školu. To je prikladan pristup za TIMSS istraživanja, jer se pohađanje škola i RPOO-a temelji na rezidencijalnom principu te učenici iz iste škole dijele i dostupnost RPOO-a te ekonomske, sociodemografske i političke karakteristike lokaliteta. No, to nije primjenjiv pristup za PISA podatke jer srednje škole obuhvaćaju puno šire teritorijalno područje, a u njih se djeca upisuju prema kriteriju prethodno postignutoga školskog uspjeha. Drugo, kao alternativnu specifikaciju procijenili smo doprinos pohađanja RPOO-a zasebno za svaku pojedinu obrazovnu skupinu roditelja, čime smo dopustili različitu snagu veze kontrolnih kovarijata s kriterijskom varijablom (npr. učinak migracijskog podrijetla ili čuvanja djece od strane rodbine može se razlikovati za obitelji u kojima roditelji imaju višu ili nižu razinu obrazovanja), što nije bio slučaj pri procjeni interakcijskog učinka u trećem koraku temeljne analize.

\section{REZULTATI}

\subsection{Razlike u obrascima participacije u RPOO-u s obzirom na obrazovanje roditelja}

U svim analiziranim istraživanjima postoji osjetna razlika u učestalosti te duljini pohađanja RPOO-a s obzirom na postignuto obrazovanje roditelja (Tablica 2). Program je vrtića dulje od godine dana pohađalo samo 16-27\% djece čiji niti jedan roditelj nije završio srednju školu, 32-53\% djece roditelja s trogodišnjom srednjom školom te 74-90\% djece čiji je barem jedan roditelj sveučilišno obrazovan. lako je obuhvaćenost djece jasličkim programima niža, slične su razlike vidljive i u učestalosti pohađanja programa jaslica. Također, i među polaznicima je prosječno trajanje pohađanja RPOO-a za 1,2-1,5 godina kraće kod djece čiji niti jedan roditelj nema srednje obrazovanje u odnosu na djecu sa sveučilišno obrazovanim roditeljem. Ovaj je raspon sličan u svim istraživanjima analiziranima u ovom radu. 
Tablica 2. Pohađanje RPOO-a prema najvišem postignutom obrazovanju roditelja

\begin{tabular}{|c|c|c|c|c|c|}
\hline & PISA-2009 & PISA-2012 & PISA-2015 & TIMSS-2011 & TIMSS-2015 \\
\hline $\begin{array}{l}\text { pohađali RPOO dulje od } \\
\text { godinu dana (zbirno) }\end{array}$ & $51,8 \%$ & $50,4 \%$ & $57,6 \%$ & $64,5 \%$ & $73,6 \%$ \\
\hline $\begin{array}{l}\text { oba roditelja bez srednje } \\
\text { škole }\end{array}$ & $15,9 \%$ & $18,3 \%$ & $17,8 \%$ & $20,5 \%$ & $27,2 \%$ \\
\hline trogodišnja srednja škola & $32,6 \%$ & $31,6 \%$ & $39,9 \%$ & \multirow[b]{2}{*}{$59,2 \%$} & $52,8 \%$ \\
\hline $\begin{array}{l}\text { četverogodišnja srednja } \\
\text { škola }\end{array}$ & $52,2 \%$ & $48,3 \%$ & $55,0 \%$ & & $71,3 \%$ \\
\hline stručni studij & $62,5 \%$ & $61,7 \%$ & $63,3 \%$ & $82,1 \%$ & $81,9 \%$ \\
\hline sveučilišni studij & $73,7 \%$ & $71,8 \%$ & $76,6 \%$ & $87,8 \%$ & $90,4 \%$ \\
\hline $\begin{array}{l}\text { pohađali program jaslica } \\
\text { (zbirno) }\end{array}$ & $18,0 \%$ & - & $23,4 \%$ & - & $29,3 \%$ \\
\hline $\begin{array}{l}\text { oba roditelja bez srednje } \\
\text { škole }\end{array}$ & $5,2 \%$ & - & $3,0 \%$ & - & $8,5 \%$ \\
\hline trogodišnja srednja škola & $11,3 \%$ & - & $14,7 \%$ & - & $19,0 \%$ \\
\hline $\begin{array}{l}\text { četverogodišnja srednja } \\
\text { škola }\end{array}$ & $19,2 \%$ & - & $21,2 \%$ & - & $27,6 \%$ \\
\hline stručni studij & $22,3 \%$ & - & $29,3 \%$ & - & $37,7 \%$ \\
\hline sveučilišni studij & $23,5 \%$ & - & $32,3 \%$ & - & $36,0 \%$ \\
\hline $\begin{array}{l}\text { prosječno trajanje } \\
\text { pohađanja RPOO-a (u } \\
\text { godinama, samo polaznici; } \\
\text { zbirno) }\end{array}$ & - & - & 2,7 & 2,9 & 3,1 \\
\hline $\begin{array}{l}\text { oba roditelja bez srednje } \\
\text { škole }\end{array}$ & - & - & 1,8 & 1,7 & 2,2 \\
\hline trogodišnje srednje škole & - & - & 2,2 & \multirow[b]{2}{*}{2,8} & 2,6 \\
\hline $\begin{array}{l}\text { četverogodišnje srednje } \\
\text { škole }\end{array}$ & - & - & 2,5 & & 2,9 \\
\hline stručni studij & - & - & 2,9 & 3,1 & 3,3 \\
\hline sveučilišni studij & - & - & 3,0 & 3,2 & 3,4 \\
\hline
\end{tabular}




\subsection{Provjera hipoteze o općem doprinosu pohađanja RPOO-a postignuću učenika}

U četvrtom razredu osnovne škole, u okviru TIMSS istraživanja, opažena razlika u razini postignuća između djece koja su pohađala RPOO dulje od godine dana i one koja nisu iznosi između 21 i 26 bodova te je nešto izraženija u matematici (Slika 1). Međutim, regresijskom analizom koja je uključivala obrazovanje roditelja i druge kontrolne kovarijate izoliran je bitno niži doprinos pohađanja RPOO-a, koji u TIMSS-2011 istraživanju iznosi otprilike 6 bodova, a u TIMSS-2015 istraživanju ne prelazi razinu statističke značajnosti.

Slika 1. Doprinos pohađanja RPOO-a u trajanju duljem od godine dana postignuću desetogodišnjaka (četvrti razred osnovne škole)

$\square$ Neto razlika $\square$ Razlika s uključenim kontrolama

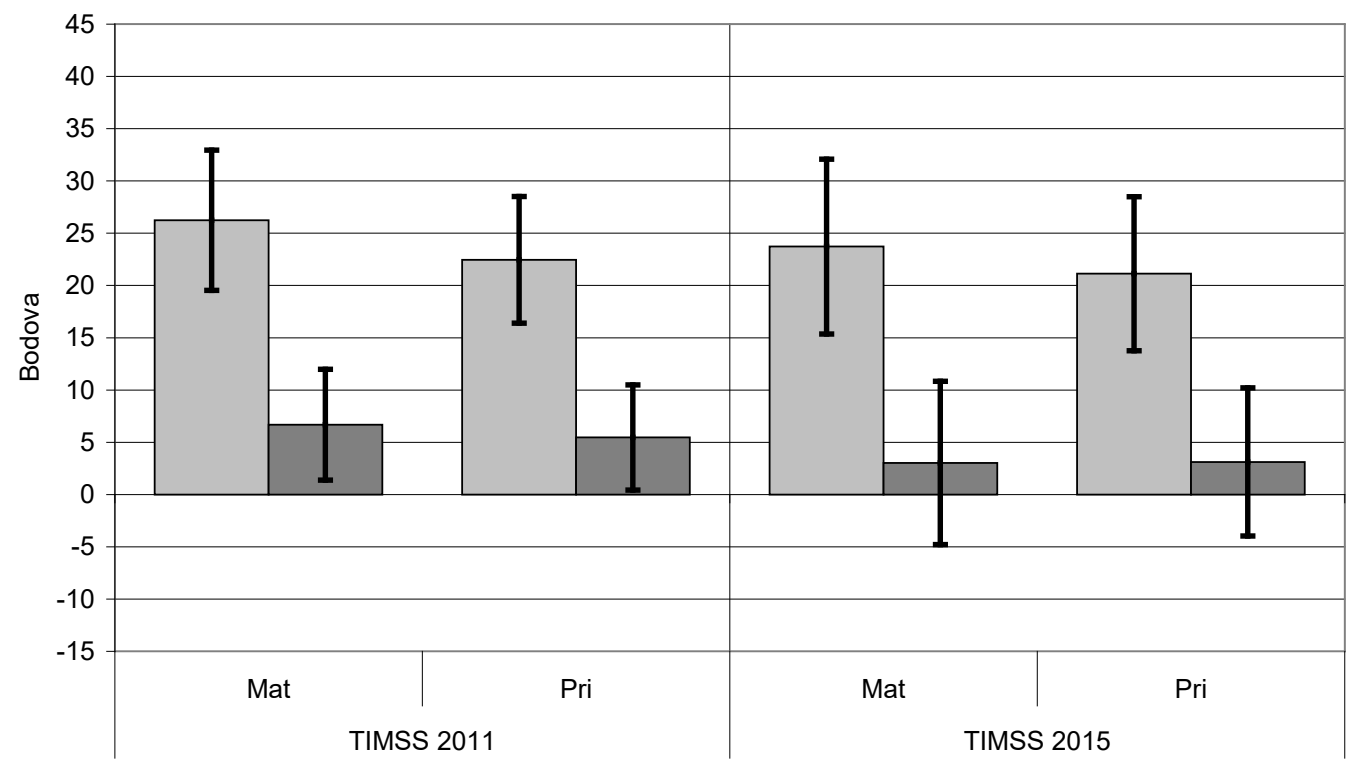

Napomena: prikazane su vrijednosti nestandardiziranog koeficijenta b (stupci) i procjena intervala pouzdanosti (linije sred stupaca) za bivarijatne specifikacije (neto) te specifikacije s punim skupom kontrolnih varijabli.

Devet godina nakon početka školovanja, PISA istraživanja pružaju sličnu sliku (Slika 2). Djeca koja su pohađala RPOO dulje od godine dana na testovima su postigla, ovisno o godini i području, 22-35 bodova više od djece koja nisu pohađala RPOO. No, i ovdje je nakon uključivanja obrazovanja roditelja i drugih ko- 
varijata u regresijski model doprinos pohađanja RPOO-a značajno slabiji te na razini statističke značajnosti konzistentno pozitivan samo u području matematike. Ipak, nešto je snažniji doprinos (oko 11 bodova za sva tri područja) ustanovljen u PISA-2015 istraživanju, u kojem je instrument o pohađanju RPOO-a bio precizan i detaljan te temeljen na unosima roditelja, a pokazatelj uže operacionaliziran kao pohađanje vrtićkog programa.

Slika 2. Doprinos pohađanja RPOO-a u trajanju duljem od godine dana postignuću petnaestogodišnjaka

$\square$ Neto razlika $\square$ Razlika s uključenim kontrolama

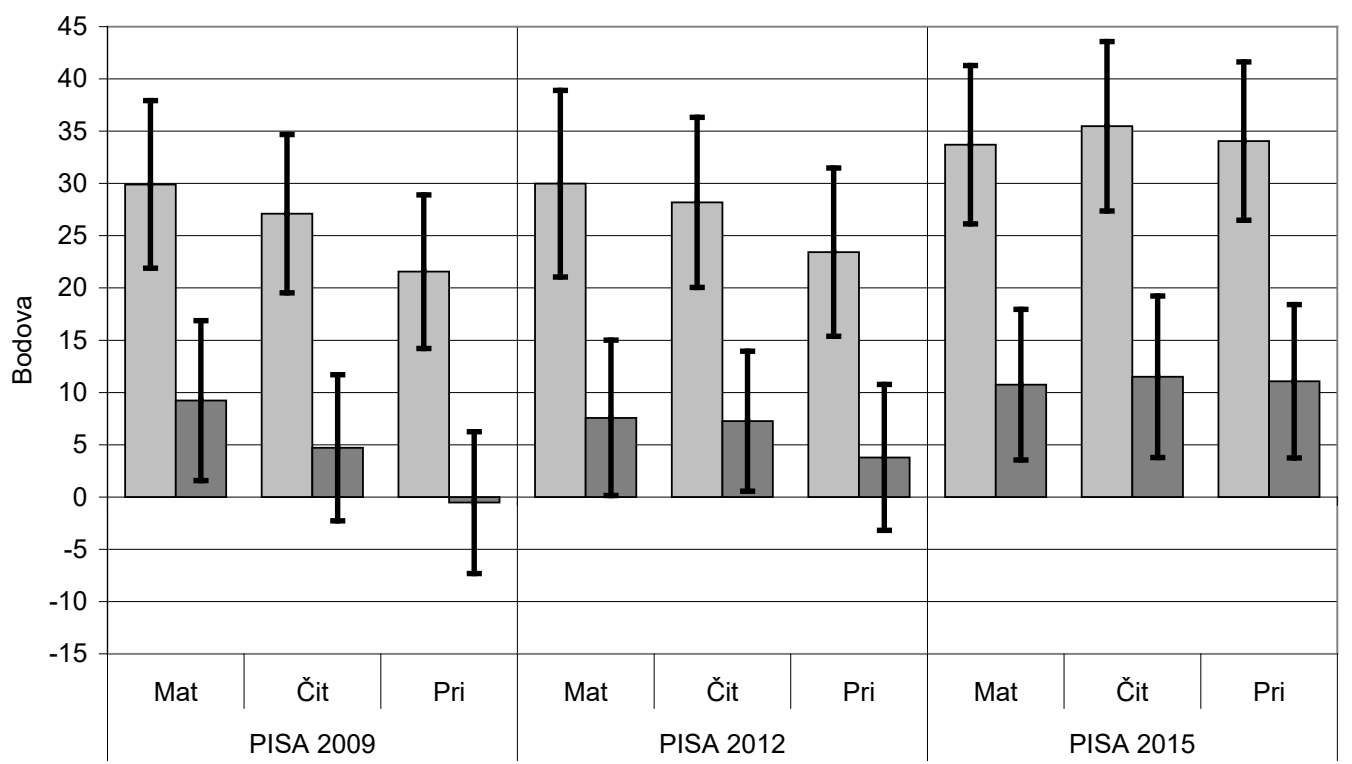

Napomena: vidjeti napomenu ispod Slike 1.

Sumarno, u 8 od 13 analiza te u četirima od pet istraživanja utvrđen je statistički značajan doprinos pohađanja RPOO-a postignuću na testovima procijenjen na 6 do 12 bodova. Doprinos je češće utvrđen u slučaju matematike (4 od 5 analiza) i u slučajevima kad su odgovore o pohađanju RPOO-a davali roditelji (5 od 7 analiza) te nije evidentno njegovo smanjivanje u kasnijem stadiju obrazovanja, odnosno u PISA naspram TIMSS istraživanja.

Kad je posrijedi pohađanje jasličkog programa (Slika 3), u PISA-2009 i TIMSS-2015 istraživanjima s uključivanjem kovarijata doprinos pohađanja postignuću prestaje biti statistički značajan u svim mjerenim područjima. Iznimka je PISA-2015 
istraživanje, u kojem je upit o pohađanju jaslica detaljno definiran, a u kojem je i nakon uključivanja kovarijata procjena doprinosa pohađanja programa jaslica zadržana na razini statističke značajnosti u svim trima područjima procjene. Dodatnom analizom na PISA-2015 podacima, u kojoj smo istodobno uzeli u obzir pohađanje programa jaslica i pohađanje programa vrtića, utvrdili smo statistički značajan doprinos pohađanja jaslica ( 8,3 boda) isključivo za test čitalačke pismenosti, dok je u ostalim područjima doprinos povezan isključivo s pohađanjem vrtića.

Slika 3. Doprinos pohađanja programa jaslica postignuću učenika

$\square$ Neto razlika $\square$ Razlika s uključenim kontrolama

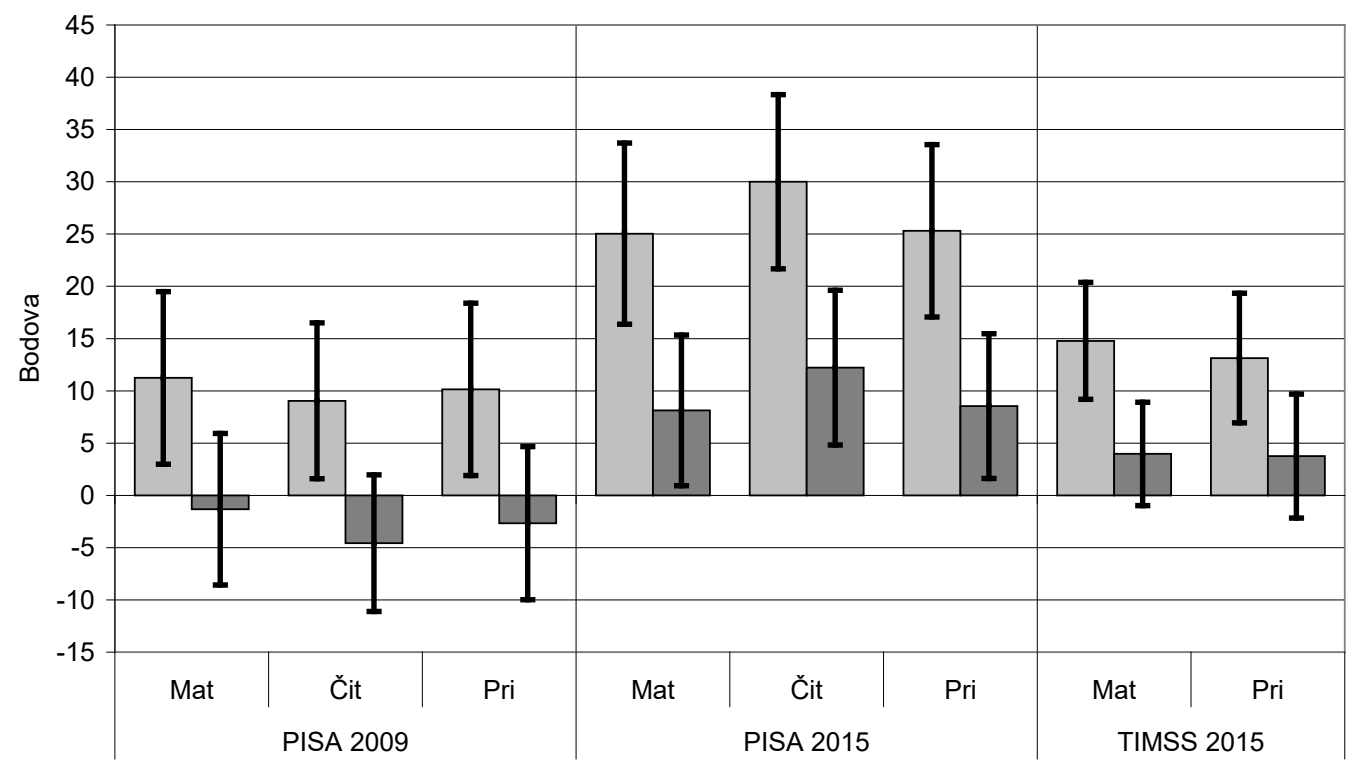

Napomena: vidjeti napomenu ispod Slike 1.

U trima istraživanjima skup kontekstualnih informacija omogućio je procjenu doprinosa trajanja pohađanja RPOO-a postignuću učenika. Trajanje pohađanja RPOO-a u multivarijatnoj je soluciji bilo pozitivno povezano s uspjehom u četirima od sedam analiza (Slika 4). U PISA-2015 istraživanju, koje je omogućilo valjaniji i pouzdaniji izračun trajanja pohađanja RPOO-a od ostalih istraživanja, doprinos je jedne godine procijenjen na otprilike 4 boda, dok je u TIMSS istraživanjima bio upola manji. 
Slika 4. Doprinos jedne godine pohađanja RPOO-a postignuću učenika

$\square$ Neto razlika $\square$ Razlika s uključenim kontrolama

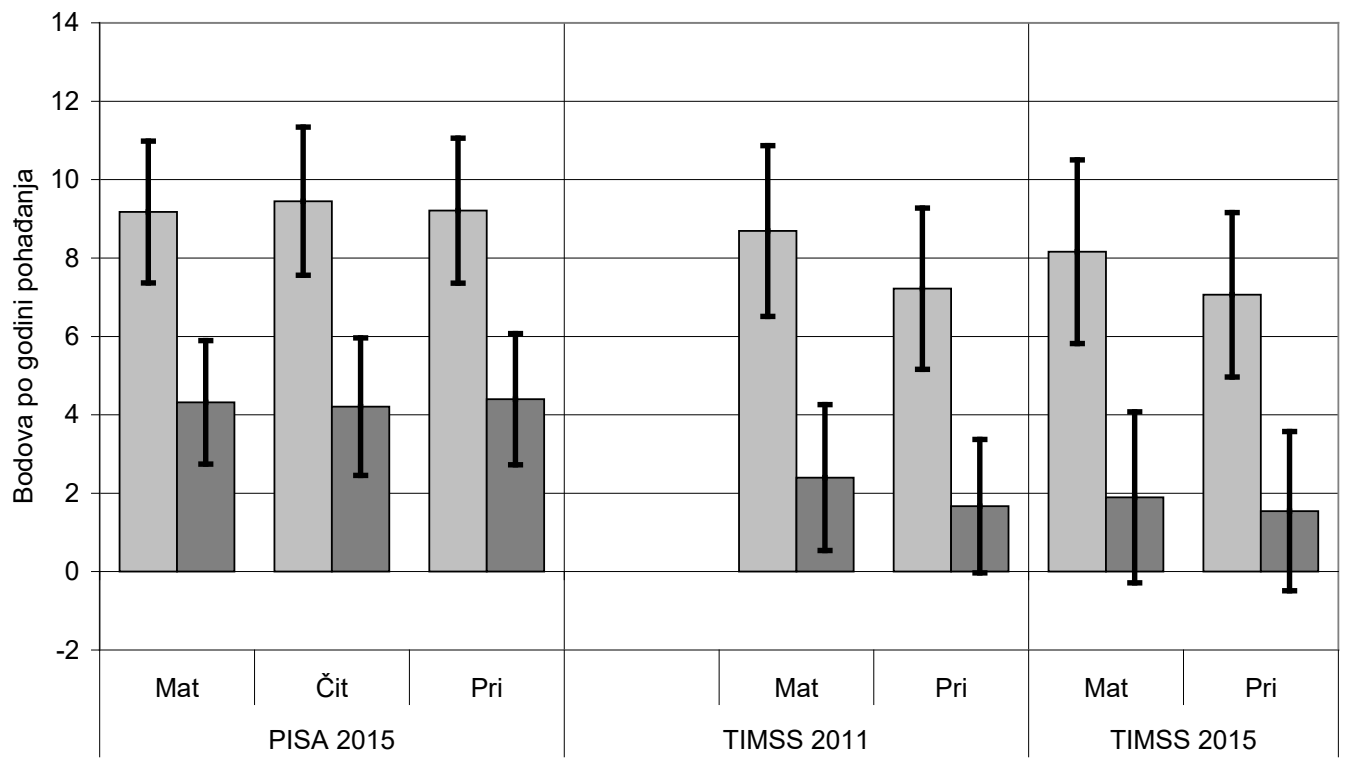

Napomena: vidjeti napomenu ispod Slike 1.

Veličina i statistička značajnost doprinosa za svako od istraživanja i područja mjerenja prikazani su u Tablici 3, kao i rezultati alternativne specifikacije kojom je kontroliran i idiosinkratični učinak svake pojedine škole, odnosno lokaliteta na postignuće učenika u TIMSS istraživanjima (brojke unutar zagrada). Alternativna je specifikacija u svim slučajevima rezultirala nešto nižim procjenama doprinosa pohađanja RPOO-a na postignuća učenika. 
Tablica 3. Rezultati OLS regresijskih analiza: doprinos pohađanja RPOO-a na postignuće učenika

\begin{tabular}{|c|c|c|c|c|c|c|c|c|c|c|c|c|c|}
\hline & \multicolumn{2}{|c|}{ TIMSS 2011} & \multicolumn{2}{|c|}{ TIMSS 2015} & \multicolumn{3}{|c|}{ PISA 2009} & \multicolumn{3}{|c|}{ PISA 2012} & \multicolumn{3}{|c|}{ PISA 2015} \\
\hline & Mat & Pri & Mat & Pri & Mat & Čit & Pri & Mat & Čit & Pri & Mat & Čit & Pri \\
\hline $\begin{array}{l}\text { pohađanje } \\
\text { u trajanju } \\
\text { većem od } \\
\text { godinu dana }\end{array}$ & $\begin{array}{l}6,7^{*} \\
(5,4)\end{array}$ & $\begin{array}{c}5,5^{*} \\
\left(5,3^{*}\right)\end{array}$ & $\begin{array}{c}3,0 \\
(1,7)\end{array}$ & $\begin{array}{c}3,1 \\
(1,0)\end{array}$ & $9,2^{*}$ & 4,7 & $-0,5$ & $7,6^{*}$ & $7,3^{*}$ & 3,8 & $10,7^{*}$ & $11,5^{*}$ & $11,1^{*}$ \\
\hline $\begin{array}{l}\text { pohađanje } \\
\text { jaslica }\end{array}$ & - & - & $\begin{array}{c}4,0 \\
(1,2)\end{array}$ & $\begin{array}{c}3,8 \\
(0,0)\end{array}$ & $-1,3$ & $-4,6$ & $-2,7$ & - & - & - & $8,1^{*}$ & $12,2^{*}$ & $8,5^{*}$ \\
\hline $\begin{array}{l}\text { doprinos } \\
\text { jedne } \\
\text { godine } \\
\text { pohađanja }\end{array}$ & $\begin{array}{l}2,4^{*} \\
(1,9)\end{array}$ & $\begin{array}{c}1,7^{*} \\
(1,5)\end{array}$ & $\begin{array}{c}1,9 \\
(1,2)\end{array}$ & $\begin{array}{c}1,5 \\
(0,5)\end{array}$ & - & - & - & - & - & - & $4,3^{*}$ & $4,2^{*}$ & $4,4^{*}$ \\
\hline
\end{tabular}

${ }^{*} p<0,05$

Napomena: prikazana je prosječna vrijednost nestandardiziranog koeficijenta b za specifikacije s punim skupom kontrolnih varijabli. Kod TIMSS istraživanja brojevi u zagradi odnose se na rezultate alternativne specifikacije u koje je uvršten fiksni učinak pojedine škole, odnosno lokaliteta.

\subsection{Provjera hipoteze o kompenzacijskom učinku RPOO-a}

U posljednjoj analizi istražili smo hipotezu o kompenzacijskom učinku pohađanja RPOO-a, odnosno postojanje snažnije povezanosti pohađanja RPOO-a i postignuća u PISA i TIMSS istraživanjima kod djece čiji roditelji imaju nižu razinu obrazovanja. U ovom koraku analize u regresijsku je analizu uključena i interakcija pohađanja RPOO-a te razine obrazovanja roditelja, uz zadržavanje kontrolnih varijabli vezanih uz materijalni status (Tablica 4).

Pretpostavljeni obrazac pronađen je u TIMSS-2011 (doprinos pohađanja RPOO-a najsnažniji je za djecu roditelja s osnovnim i srednjim obrazovanjem) te PISA-2015 istraživanju (doprinos pohađanja RPOO-a izražen je za djecu roditelja s trogodišnjim srednjim obrazovanjem). No, u TIMSS-2015 i PISA-2009 istraživanjima doprinos pohađanja RPOO-a identificiran je samo za djecu čiji roditelji imaju završen stručni studij, a u PISA-2012 i PISA-2015 istraživanjima djeca (svih) visokoobrazovanih roditelja. Obrasci nalaza slični su promatra li se doprinos trajanja pohađanja RPOO, dok kod jaslica ne postoje naznake potpore hipotezi o kompenzacijskom učinku pohađanja. 
Tablica 4. Ukupni učinak pohađanja RPOO-a na postignuće s obzirom na obrazovanje roditelja: rezultati OLS regresijskih analiza koje uključuju interakcije pohađanja RPOO-a i razine obrazovanja roditelja

\begin{tabular}{|c|c|c|c|c|c|c|c|c|c|c|c|c|c|}
\hline & \multicolumn{2}{|c|}{ TIMSS 2011} & \multicolumn{2}{|c|}{$\begin{array}{l}\text { TIMSS } \\
2015\end{array}$} & \multicolumn{3}{|c|}{ PISA 2009} & \multicolumn{3}{|c|}{ PISA 2012} & \multicolumn{3}{|c|}{ PISA 2015} \\
\hline & Mat & Pri & Mat & Pri & Mat & Čit & Pri & Mat & Čit & Pri & Mat & Čit & Pri \\
\hline \multicolumn{14}{|c|}{$\begin{array}{l}\text { pohađanje u trajanju } \\
\text { većem od godinu dana }\end{array}$} \\
\hline $\begin{array}{l}\text { oba roditelja bez } \\
\text { srednje škole }\end{array}$ & $22,8^{*}$ & 19,0 & $-5,8$ & 0,3 & $-6,1$ & $-10,0$ & $-22,7^{*}$ & $-11,3$ & 6,3 & $-5,9$ & 8,7 & 12,5 & $-0,8$ \\
\hline $\begin{array}{l}\text { trogodišnja srednja } \\
\text { škola }\end{array}$ & \multirow{2}{*}{$6,8^{*}$} & \multirow{2}{*}{$6,9^{*}$} & 4,1 & 3,3 & 6,9 & 3,9 & $-1,9$ & 1,3 & $-0,2$ & $-0,9$ & 11,7 & $14,8^{*}$ & $14,4^{*}$ \\
\hline $\begin{array}{l}\text { četverogodišnja } \\
\text { srednja škola }\end{array}$ & & & 2,3 & 1,1 & 10,8 & 5,7 & 0,5 & 2,5 & 2,7 & 1,6 & 1,1 & 2,0 & 1,6 \\
\hline stručni studij & 9,5 & 2,8 & $18,4^{*}$ & $21,3^{*}$ & $19,5^{*}$ & 8,7 & 5,1 & 14,3 & $15,4^{*}$ & 10,7 & $21,7^{*}$ & $21,0^{*}$ & $21,1^{*}$ \\
\hline sveučilišni studij & $-5,2$ & $-10,3$ & $-6,6$ & $-3,7$ & 3,7 & 3,5 & $-0,8$ & $23,2^{*}$ & $18,5^{*}$ & $16,7^{*}$ & $19,5^{*}$ & $18,4^{*}$ & $18,8^{*}$ \\
\hline \multicolumn{14}{|l|}{ pohađanje jaslica } \\
\hline $\begin{array}{l}\text { oba roditelja bez } \\
\text { srednje škole }\end{array}$ & - & - & $-3,1$ & 2,4 & $-7,0$ & $-7,8$ & 2,9 & - & - & - & 9,9 & 33,9 & 1,9 \\
\hline $\begin{array}{l}\text { trogodišnja srednja } \\
\text { škola }\end{array}$ & - & - & 3,8 & 5,9 & 1,5 & $-6,1$ & $-3,3$ & - & - & - & 7,9 & 11,2 & 9,9 \\
\hline $\begin{array}{l}\text { četverogodišnja } \\
\text { srednja škola }\end{array}$ & - & - & $7,8^{*}$ & 5,1 & 3,1 & 0,9 & 0,2 & - & - & - & 2,0 & 7,4 & 3,2 \\
\hline stručni studij & - & - & 6,4 & 8,7 & $-12,9$ & $-13,0$ & $-16,2$ & - & - & - & 10,2 & $14,8^{*}$ & 10,0 \\
\hline sveučilišni studij & - & - & $-3,0$ & $-1,8$ & $-2,4$ & $-7,3$ & 0,8 & - & - & - & $13,2^{*}$ & $15,7^{*}$ & $12,7^{*}$ \\
\hline \multicolumn{14}{|c|}{$\begin{array}{l}\text { doprinos jedne godine } \\
\text { pohađanja }\end{array}$} \\
\hline $\begin{array}{l}\text { oba roditelja bez } \\
\text { srednje škole }\end{array}$ & 6,9 & 5,2 & 0,7 & 2,9 & - & - & - & - & - & - & 3,3 & $8,5^{*}$ & 2,1 \\
\hline $\begin{array}{l}\text { trogodišnja srednja } \\
\text { škola }\end{array}$ & \multirow{2}{*}{$2,6^{*}$} & \multirow{2}{*}{2,4} & 2,0 & 1,4 & - & - & - & - & - & - & $4,6^{*}$ & $5,8^{*}$ & $5,9^{*}$ \\
\hline $\begin{array}{l}\text { četverogodišnja } \\
\text { srednja škola }\end{array}$ & & & 1,7 & 0,9 & - & - & - & - & - & - & $2,8^{*}$ & 2,6 & $2,9^{*}$ \\
\hline stručni studij & 3,4 & 0,6 & $6,4^{*}$ & $7,1^{*}$ & - & - & - & - & - & - & $4,4^{*}$ & $4,0^{*}$ & $4,2^{*}$ \\
\hline sveučilišni studij & $-1,5$ & $-3,7$ & $-1,0$ & $-0,8$ & - & - & - & - & - & - & $5,7^{*}$ & $5,3^{*}$ & $5,5^{*}$ \\
\hline
\end{tabular}

${ }^{*} p<0,05$

Napomena: prikazana je prosječna vrijednost nestandardiziranog koeficijenta b za specifikacije $s$ punim skupom kontrolnih varijabli. Prikazana vrijednost uključuje opći doprinos pohađanja RPOO-a i specifični doprinos pohađanja RPOO-a vezan uz stupanj obrazovanja roditelja, ali ne i opći doprinos stupnja obrazovanja roditelja. Prikazani rezultati i procjena standardne pogreške temelje se na analizama svih vjerojatnih vrijednosti sudionika na testovima i uz korištenje replikacijskih utežanja priloženih uz skup podataka. 
Alternativni pristupi analizi dodavanjem dummy varijabli na razini škole (TIMSS), odnosno zasebnih analiza za svaku razinu obrazovanja roditelja (PISA), u pojedinim su slučajevima doveli do nižih procjena doprinosa pohađanja RPOO-a, ali je obrazac nalaza postojan (ishodi tih analiza dostupni su na zahtjev).

\section{ZAKLJUČNA RASPRAVA}

Većina analiza PISA i TIMSS podataka utvrdila je određeni opći doprinos dugotrajnijeg pohađanja RPOO-a na razinu postignuća učenika u Hrvatskoj u području matematičke, prirodoslovne i čitalačke pismenosti, a koji se ne može objasniti obrazovanjem ili zanimanjem roditelja, migracijskim podrijetlom, sastavom kućanstva ili obilježjima lokalne sredine. Takvi nalazi idu u prilog dosadašnjim studijama koje su također naišle na dugoročniji pozitivan učinak pohađanja RPOO-a na kasnije obrazovne ishode kod djece (npr. Andresson, 1992; Sylva i dr., 2004; Lowe Vandell i dr., 2010; European Commission, 2014). Važno je istaknuti i kako naše analize nisu ukazale na to da je dugoročniji učinak pohađanja RPOO-a (devet godina nakon početka školovanja, PISA) slabiji ili rjeđi u odnosu na kratkoročniji učinak (četiri godine nakon početka školovanja, TIMSS). Nalazi su robusni s obzirom na različit dostupan skup kovarijata SES-a obitelji i obilježja lokalne sredine, različite izvore informacija o pohađanju RPOO-a i obrazovanju roditelja, a perzistentni su i pri korištenju alternativnih specifikacija modela.

U samo jednom od triju istraživanja utvrđen je pozitivan doprinos pohađanja jasličkih programa. Doduše, riječ je o PISA-2015 istraživanju, u kojem je instrument o pohađanju RPOO-a bio najprecizniji i najdetaljniji te su podaci temeljeni na unosima roditelja i stoga je taj instrument u znatno većoj mjeri valjan i pouzdaniji od ostalih. Rezultati na tragu ranijih inozemnih istraživanja učinka pohađanja jasličkih programa na kognitivni razvoj polaznika koja uglavnom upućuju na dugoročnije pozitivne učinke (Andersson, 1989, 1992; NICHD ECCRN, 2000; Sylva i dr., 2004; Belsky i dr., 2007; Felfe i Lalive, 2010).

Učinak godine pohađanja RPOO-a na postignuća učenika od 4,4 boda u hrvatskom PISA-2015 istraživanju upola je manji od 9 bodova procijenjenih na cjelovitim PISA-2015 podacima koji obuhvaćaju sve zemlje sudionice (OECD, 2017b: 154). Također, opažena prednost polaznika u Hrvatskoj (koja u slučaju pohađanja RPOO-a duljeg od godinu dana, primjerice, iznosi do 35 bodova) većinom proizlazi iz kompozicijskog učinka učestalijeg pohađanja RPOO-a djece iz obitelji višeg SES-a. Konačni modeli pokazuju kako se pohađanju RPOO-a može pripisati doprinos od najviše 12 bodova postignuću na testovima, što predstavlja jednu šestinu "razine znanja" u TIMSS i PISA testovima. Međutim, ni ta povezanost nužno ne ukazuje na uzročni karakter ove veze zbog mogućeg učinka samoselekcije. 
Primjerice, samo pohađanje RPOO-a može ukazivati na veću angažiranost roditelja oko obrazovanja djeteta. ${ }^{6}$ Ipak, uz pretpostavku kauzalnoga linearnog učinka pohađanja te najsnažnijega utvrđenog doprinosa (4,4 po godini pohađanja prema PISA-2015 istraživanju), moguće je temeljem ovih rezultata simulirati potencijalni učinak širenja pohađanja RPOO-a sa stanja zatečenog PISA-2015 istraživanjem na razinu općeg pohađanja gdje bi svako dijete RPOO pohađalo ukupno pet godina. U tom bi slučaju pohađanje RPOO-a moglo voditi povećanju prosječnog uspjeha na PISA testovima na nacionalnoj razini za do 15 bodova, dakle za petinu "razine znanja" ili postignuće od pola godine školovanja.

Nalaz o općem doprinosu pohađanja RPOO-a na razinu kasnijih postignuća u matematičkoj, prirodoslovnoj i jezičnoj pismenosti treba sagledati i u kontekstu strukture polaznika. Naime, ustanovili smo izrazite nejednakosti u učestalosti i trajanju pohađanja programa s obzirom na SES roditelja, posebno razinu njihova obrazovanja, što znači da i korist od pohađanja programa ponajprije uživaju djeca pripadnika viših društvenih slojeva. To ukazuje na mehanizam efektivnog održavanja nejednakosti u obrazovanju (Lucas, 2001), odnosno postupaka kojima pripadnici viših slojeva uključivanjem djece u aktivnosti izvan i prije okvira obaveznog i redovnog školovanja osiguravaju svojoj djeci prednost u obrazovnim postignućima. Međutim, imajući u vidu da opažena razlika u postignuću djece na PISA i TIMSS testovima (Tablica P2 u Prilozima) između djece roditelja s trogodišnjim i sveučilišnim obrazovanjem iznosi 56-88 bodova, utvrđeni doprinos (ne)pohađanja RPOO-a od 6-12 bodova očito ne predstavlja primarni mehanizam efektivnog održavanja obrazovnih nejednakosti, ali mu u određenoj mjeri pridonosi. Nadalje, s obzirom na to da je među djecom visokoobrazovanih roditelja u Hrvatskoj gotovo postignuta puna obuhvaćenost RPOO-om, svako će daljnje širenje kapaciteta sustava RPOO-a najvećim dijelom dolaziti u vidu povećanja sudjelovanja djece nižeg SES-a. To će pak, sukladno konceptu maksimalno održane nejednakosti (maximal maintained inequality; Raftery i Hout, 1993), izgledno pridonijeti smanjenju nejednakosti u postignućima djece na testovima.

Konačno, nije pronađena sustavna potpora hipotezi o kompenzacijskom učinku pohađanja RPOO-a, odnosno snažnijem doprinosu pohađanja RPOO-a za postignuća djece slabijeg SES-a. Štoviše, u PISA istraživanjima provedenima s petnaestogodišnjacima, učinak je pohađanja RPOO-a izraženiji za djecu visokoobrazovanih roditelja. Ti su nalazi suprotni onima dobivenima u drugim europskim zemljama

Npr. u TIMSS istraživanju roditelji su četverogodišnjega strukovnog obrazovanja i stručnih studija (2015) odnosno srednjeg obrazovanja (2011) koji su upisali djecu u RPOO prije polaska u školu prakticirali nešto više obrazovnih aktivnosti s djecom od roditelja iste razine obrazovanja čija djeca nisu išla u RPOO. Također, isti čimbenici koji utječu na odluku o pohađanju RPOO-a mogu biti povezani s odlukom o pohađanju gimnazije, čime bi učinak pohađanja RPOO-a za srednjoškolce u PISA istraživanju mogao biti precijenjen. 
koji govore u prilog većem doprinosu pohađanja RPOO-a za djecu nižeg SES-a (npr., za Francusku: Dumas i LeFranc, 2010; za Norvešku: Havnes i Mogstad, 2011; za Ujedinjeno Kraljevstvo: Sylva i dr., 2004; za Italiju: Brili, Del Boca i Pronzato, 2011). No, ta su istraživanja provođena u zemljama koje imaju bitno višu obuhvaćenost djece RPOO-om (Eurostat, 2018), dok je u Hrvatskoj za djecu nižeg SES-a ona vrlo niska (Dobrotić, Matković i Menger, 2018) te izostanak nalaza o kompenzacijskom učinku u našim analizama može proizlaziti već iz same selektivnosti pohađanja RPOO-a u Hrvatskoj, jer doista deprivirana djeca koja bi imala najviše koristi dječji vrtić nisu ni pohađala (usp. Pećnik, 2013; Šućur i dr., 2015). Kompenzacijski učinak može biti zasjenjen i zbog primjena strategija efektivnog održavanja nejednakosti koje se manifestiraju u vidu bolje kvalitete odgojno-obrazovnog procesa te veće dostupnosti i priuštivosti dodatnih (plaćenih) aktivnosti za djecu roditelja višeg SES-a (vidjeti Pećnik, 2013; Dobrotić, Matković i Menger, 2018), što upućuje na potrebu dodatnih istraživanja koja bi ispitivala i te aspekte.

Prethodno spomenuta ograničenja inherentna su krossekcijskoj prirodi istraživanja na kojem naše analize počivaju. Za njihovo vjerodostojno prevladavanje bilo bi potrebno poduzeti longitudinalni pristup, uz primjenu eksperimentalnog nacrta alokacijom djece u definiranu intervenciju. Međutim, tad se pojavljuje problem generalizacije, posebice stoga što primjena takvog nacrta ne bi bila etički prihvatljiva za djecu iz svih društvenih klasa (nužno bi uključivala uskraćivanje u odnosu na izostanak intervencije). Alternativno, moguće je istražiti doseg kvazieksperimentalnog pristupa, temeljenog na razlikama i promjenama u dostupnosti i priuštivosti RPOO-a u različitim jedinicama lokalne samouprave (koje nose isključivu nadležnost za taj sustav), a što bi tražilo skup podataka koji uključuje detaljne informacije o postignuću, socioekonomskom statusu te preciznom mjestu odrastanja više generacija, kao i mogućnostima pohađanja RPOO za svaku lokaciju i godinu. Također, ograničenje generalizaciji zaključaka predstavlja činjenica da se te analize odnose na djecu koja su pohađala RPOO u razdoblju između 1995. i 2011. No, u međuvremenu nije došlo do većih strukturnih promjena u regulaciji, organizaciji ili financiranju RPOO-a (vidjeti u Dobrotić, Matković i Menger, 2018), tako da nalaze možemo smatrati primjenjivima i na postojeći sustav RPOO-a, a što će biti moguće i empirijski provjeriti u ciklusima PISA-2018 i TIMSS-2019. Konačno, značajno je ograničenje analiza temeljenih na PISA i TIMSS testovima što ispituju isključivo doprinos pohađanja RPOO-a postignućima u pismenosti, odnosno tek jednom podskupu kognitivnih ishoda kod djece. Pohađanje RPOO-a pridonosi i socioemocionalnom razvoju djece, iznimno bitnom za dobrobit djeteta, a koji nisu predmet tih istraživanja. 


\section{LITERATURA}

Andersson B-E (1989). Effects of Public Day-Care-ALongitudinal Study, Child Development, 60 (1): 857-866. https://doi.org/10.2307/1131027

Andersson B-E (1992). Effects of Day-Care on Cognitive and Socioemotional Competence of Thirteen-Year-Old Swedish Schoolchildren, Child Development, 63 (1): 20-36. https:// doi.org/10.1111/j.1467-8624.1992.tb03592.x

Antulić Majcen S i Pribela-Hodap S (2017). Prvi koraci na putu prema kvaliteti: samovrednovanje ustanova ranoga i predškolskoga odgoja i obrazovanja. Zagreb: Nacionalni centar za vanjsko vrednovanje obrazovanja.

Babarović T, Burušić J i Šakić M (2009). Uspješnost predviđanja obrazovnih postignuća učenika osnovnih škola Republike Hrvatske, Društvena istraživanja, 18 (4-5): 673-695.

Barnett WS (1995). Long-term effects of early childhood programs on cognitive and school outcomes, The Future of Children, 5 (3): 25-50. https://doi.org/10.2307/1602366

Belsky J (1988). The 'effects' of infant day care reconsidered, Early Childhood Research Quarterly, 3 (3): 235-272. https://doi.org/10.1016/0885-2006(88)90003-8

Belsky J, Lowe Vandell D, Burchinal M, Clarke-Stewart KA, McCartney K, Tresch Owen M i NICHD Early Child Care Research Network (2007). Are There Long-Term Effects of Early Child Care?, Child Development, 78 (2): 681 - 701. https://doi.org/10.1111/j.14678624.2007.01021.x

Bradley RH i Corwyn RF (2002). Socioeconomic status and child development. Annual Review of Psychology, 53 (1): 371-399. https://doi.org/10.1146/annurev. psych.53.100901.135233

Braš Roth M, Gregurović M, Markočić DekanićAi Markuš M (2007). PISA 2006. Prirodoslovne kompetencije za život. Prvi hrvatski rezultati - sažeti pregled. Zagreb: Nacionalni centar za vanjsko vrednovanje obrazovanja.

Breen R i Jonsson JO (2005). Inequality of Opportunity in Comparative Perspective: Recent Research on Educational Attainment and Social Mobility, Annual Review of Sociology, 31 (1): 223-243. https://doi.org/10.1146/annurev.soc.31.041304.122232

Bridges M, Fuller B, Rumberger R i Tran L (2004). Preschool for California's children: Promising benefits, unequal access, PACE Policy Brief 04-3. Berkeley: Policy Analysis for California Education.

Brili Y, Del Boca D i Pronzato C (2011). Exploring the impacts of public childcare on mothers and children in Italy: Does rationing play a role?, IZA Discussion Paper No. 5918. https:// ssrn.com/abstract=1921969.

Bodovski K, Kotok S i Henck A (2014). Universal patterns or the tale of two systems? Mathematics achievement and educational expectations in post-socialist Europe, Compare: A Journal of Comparative and International Education, 44 (5): 723-755. https://doi.org/10.1080/03057925.2013.792670

Bourdieu P (1977). Cultural Reproduction and Social Reproduction. U: Karabel J i Halsey $\mathrm{AH}$ (ur.). Power and Ideology in Education. New York: Oxford University Press, 487-511.

Broberg AG, Wessels H, Lamb ME i Hwang P (1997). Effects of Day Care on the Development of Cognitive Abilities in 8-Year-Olds: A Longitudinal Study, Developmental Psychology, 33 (1): 62-69. https://doi.org/10.1037/0012-1649.33.1.62

Brooks-Gunn J i Duncan GJ (1997). The effects of poverty on children, Future of Children, 7 (2): 55-71. https://doi.org/10.2307/1602387 
Camilli G, Vargas S, Ryan S i Barnett WS (2010). Meta-analysis of the effects of early education interventions on cognitive and social development, Teachers College Record, 112 (3): 579-620.

Conger RD i Donnellan MB (2007). An Interactionist Perspective on the Socioeconomic Context of Human Development, Annual Review of Psychology, 58 (1): 175-199. https:// doi.org/10.1146/annurev.psych.58.110405.085551

Čudina-Obradović M (1995). Psihološka utemeljenost institucionalnog predškolskog odgoja, Napredak, 136 (1): 64-76.

Desai S, Chase-Lansdale PL i Michael RT (1989). Mother or market? Effects of maternal employment on the intellectual ability of 4-year-old children, Demography, 26 (4): 545561.

Dobrotić I, Matković T i Menger, V (2018). Analiza pristupačnosti, kvalitete, kapaciteta i financiranja sustava ranoga i predškolskog odgoja i obrazovanja u Republici Hrvatskoj. Zagreb: Ministarstvo za demografiju, obitelj, mlade i socijalnu politiku.

Duncan GJ, Brooks-Gunn J i Kato Klebanov P (1994). Economic deprivation and early childhood development, Child Development, 65 (2): 296-318. https://doi. org/10.1146/10.1111/j.1467-8624.1994.tb00752.x

Dumas C i LeFranc A (2010). Early schooling and later outcomes: Evidence from pre-school extension in France. Pontoise: Université de Cergy.

Duran M (1976). Utjecaj rada predškolskih ustanova na uspjeh u prvom razredu osnovne škole, Život $i$ škola, 28 (1-2): 83-89.

Entwisle DR, Alexander KL i Steffel Olson L. (2005). First grade and educational attainment by age 22: A new story. American Journal of Sociology, 110 (5): 1458-1502. https://doi. org/10.1146/10.1086/428444

Ermisch J (2008). Origins of Social Immobility and Inequality: Parenting and Early Child Development, National Institute Economic Review, 205 (1): 62-71. https://doi.org/10.11 46/10.1177/0027950108096589

European Commission (2014). Proposal for key principles of a Quality Framework for Early Childhood Education and Care: Report of the Working Group on Early Childhood Education and Care under the auspices of the European Commission. Luxembourg: Publications Office of the European Union.

European Commission, ECEA i Eurydice (2016). Structural Indicators for Monitoring Education and Training Systems in Europe - 2016. Eurydice Background Report to the Education and Training Monitor 2016. Luxembourg: Publications Office of the European Union.

Eurostat (2018). Pupils in early childhood and primary education by education level and age - as \% of corresponding age population. http://appsso.eurostat.ec.europa.eu/nui/show. do?dataset=educ_uoe_enrp01

Felfe C i Lalive R (2010). How does Early Child Care Affect Child Development? Learning from the Children of German Unification. https://www.econstor.eu/handle/10419/37432

Field T (1991). Quality infant daycare and grade school behavior and performance, Child Development, 62 (4): 863-870. https://doi.org/10.1146/10.1111/j.1467-8624.1991. tb01575.x

Ganzeboom HBG i Treiman DJ (1996). Internationally comparable measures of occupational status for the 1988 International Standard Classification of Occupations, Social Science Research, 25 (3): 201-239. https://doi.org/10.1146/10.1006/ssre.1996.0010 
Gilliam WS i Zigler EF (2001). A critical meta-analysis of all impact evaluations of statefunded preschool from 1977 to 1988: Implications for policy, service delivery and program evaluation, Early Childhood Research Quarterly, 15 (4): 441-473. https://doi. org/10.1146/10.1016/S0885-2006(01)00073-4

Gregurović M i Kuti S (2010). Učinak socioekonomskog statusa na obrazovno postignuće učenika: Primjer PISA istraživanja, Hrvatska 2006, Revija za socijalnu politiku, 17 (2): 179-196. https://doi.org/10.1146/10.3935/rsp.v17i2.918

Haveman R i Wolfe B (1995). The determinants of children's attainments: A review of methods and findings, Journal of Economic Literature, 33 (3): 1829-1878.

Havnes T i Mogstad M (2011). No Child Left Behind: Subsidized Child Care and Children's Long-Run Outcomes, American Economic Journal: Economic Policy, 3 (2): 97-129. https://doi.org/10.1146/10.1257/pol.3.2.97

Havnes Tarjei i Mogstad M (2012). Is Universal Child Care Leveling the Playing Field? CESifo Working Paper Series No. 4014. https://papers.ssrn.com/sol3/papers. cfm?abstract_id=2184732.

Heckman JJ i Masterov DV (2007). The Productivity Argument for Investing in Young Children, Applied Economic Perspectives and Policy, 29 (3): 446-493. https://doi. org/10.1146/10.1111/j.1467-9353.2007.00359.x

lannelli C (2002). Parental Education and Young People's Educational and Labour Market Outcomes: A Comparison across Europe. Working paper, N. 45. Mannheimer Zentrum fur Europaische Sozialforschung. http://citeseerx.ist.psu.edu/viewdoc/ download?doi=10.1.1.203.784\&rep=rep1\&type=pdf

Jokić B i Ristić Dedić Z (2010). Razlike u školskom uspjehu učenika trećih i sedmih razreda osnovnih škola u Republici Hrvatskoj s obzirom na spol učenika i obrazovanje roditelja: populacijska perspektiva, Revija za socijalnu politiku, 17 (3): 345-362. https://doi. org/10.1146/10.3935/rsp.v17i3.954

Jurčević-Lozančić A (1996). Izazovi odrastanja - predškolsko dijete u okružju suvremene obitelji i vrtića. Petrinja: Visoka učiteljska škola u Petrinji.

Karoly LA, Greenwood PW, Everingham SS, Hoube J, Kilburn RM, Rydell CP, Sanders M i Chiesa J (1998). Investing in our children: What we know and don't know about the cost and benefits of early childhood interventions. Washington: RAND Corporation.

Kogan I, Gebel M i Noelke C (2012). Educational Systems and Inequalities in Educational Attainment in Central and Eastern European Countries, Studies of Transition States and Societies, 4 (1): 69-83.

Lamb ME (1996). Effects of nonparental child care on child development: An update, Canadian Journal of Psychiatry, 41 (1): 330-342. https://doi.org/10.1146/10.1177/0706 74379604100603

Loeb S, Bridges M, Fuller B, Rumberger R i Bassok D (2007). How much is too much? The influence of preschool centers on children's social and cognitive development, Economics of Education Review, 26 (1): 52-66. https://doi.org/10.1146/10.1016/j. econedurev.2005.11.005

Lowe Vandell D, Belsky J, Burchinal M, Vandergrift N i Steinberg L (2010). Do effects of early child care extend to age 15 years? Results from the NICHD study of early child care and youth development, Child Development, 81 (3): 737-756. https://doi.org/10.1111/j.14678624.2010.01431.x 
Lucas SR (2001). Effectively Maintained Inequality: Education Transitions, Track Mobility, and Social Background Effects, American Journal of Sociology, 106 (6): 1642-1690. https://doi.org/10.1146/10.1086/321300

Martin MO, Mullis, IVS. i Hooper M (ur.) (2016). Methods and Procedures in TIMSS 2015. Boston: TIMSS \& PIRLS International Study Center.

Magnuson KA, Meyers MK, Ruhm CJ i Waldfogel J (2004). Inequality in pre-school education and school readiness, American Educational Research Journal, 41 (1): 115-157. https:// doi.org/10.1146/10.3102/00028312041001115

Magnuson KA, Ruhm CJ i Waldfogel J (2004). Does prekindergarten improve school preparation and performance?, Economics of Education Review, 26 (1): 33-51. https:// doi.org/10.1146/10.3386/w10452

Matković T (2010). Obrazovanje roditelja, materijalni status i rano napuštanje školovanja u Hrvatskoj: trendovi u proteklom desetljeću, Društvena Istraživanja, 19 (4-5): 643-667.

Matković T, Tomić I i Vehovec M (2010). Efikasnost nasuprot dostupnosti? O povezanosti troškova i ishoda studiranja u Hrvatskoj, Revija za socijalnu politiku, 17 (2): 215-237. https://doi.org/10.1146/10.3935/rsp.v17i2.919

McLoyd VC (1998). Socioeconomic disadvantage and child development, American Psychologist, 53 (2): 185-204. https://doi.org/10.1146/10.1037/0003-066X.53.2.185

Melhuish EC (2004). A Literature Review of the Impact of Early Years Provision on Young Children, with Emphasis Given to Children form Disadvantaged Backgrounds. London: National Audit Office.

Morrissey TW i Warner MEe (2007). Why early care and education deserves as much attention, or more, than prekindergarten alone, Applied developmeental science, 11 (2): 57-70. https://doi.org/10.1146/10.1080/10888690701384897

Mullis IVS i Martin MO (ur.). (2013). Timss 2015 assessment frameworks. Chestnut Hill: Timss \& Pirls.

Neuman M (2005). Governance of Early Childhood Education and Care: Recent Developments in OECD Countries, Early Years, 25 (2): 129-141. https://doi.org/10.114 6/10.1080/09575140500130992

NICHD (2000). The relation of child care to cognitive and language development, Child Development, 71 (4): 960-980. https://doi.org/10.1146/10.1111/1467-8624.00202

NICHD (2001). Before Head Start: Income and Ethnicity, Family Characteristics, Child Care Experiences, and Child Development, Early Education \& Development, 12 (4): 545-576. https://doi.org/10.1146/10.1207/s15566935eed1204_4

NICHD (2005). Early child care and children's development in the primary grades: Results from the NICHD Study of Early Child Care, American Educational Research Journal, 42 (3): 537-570. https://doi.org/10.1146/10.3102/00028312042003537

NICHD i Duncan GJ (2003). Modeling the impacts of child care quality on children's preschool cognitive development, Child Development, 74 (5): 1454-1475. https://doi. org/10.1146/10.1111/1467-8624.00617

O'Brien Caughy M, DiPietro JA i Strobino DM (1994). Day-Care Participation as a Protective Factor in the Cognitive Development of Low-Income Children, Child Development, 65 (2): 457-471. OECD (2010). Education at a Glance 2010. Paris: OECD Publishing. https://doi.org/10.1111/j.1467-8624.1994.tb00763.x

OECD (2017a) PISA 2015 Technical report. Paris: OECD Publishing.

OECD (2017b). Starting Strong 2017. Paris: OECD Publishing. 
Olsen DA (1999). Universal preschool is no golden ticket: Why government should not enter the preschool business, Policy Analysis, 333: 1-31.

Pećnik N (ur.) (2013). Kako roditelji i zajednice brinu o djeci najmlađe dobi u Hrvatskoj. Zagreb: Ured UNICEF-a za Hrvatsku.

Penn H (2009). Early childhood education and care: Key lessons from research for policy makers. Brussels: European Commission.

Pianta RC, Barnett WS, Burchinal M i Thornburg KR (2009). The effects of preschool education: What we know, how public policy is or is not aligned with the evidence base, and what we need to know, Psychological Science in the Public Interest, 10 (2): 49-88. https://doi.org/10.1146/10.1177/1529100610381908

Puzić S, Gregurović M i Košutić I (2016). Cultural Capital - A Shift in Perspective: An Analysis of PISA 2009 Data for Croatia, British Journal of Sociology of Education, 37 (7): 1056-1076. https://doi.org/10.1146/10.1080/01425692.2014.1001058

Puzić S, Gregurović M i Košutić I (2018). Kulturni kapital i obrazovne nejednakosti u Hrvatskoj, Njemačkoj i Danskoj: usporedna analiza PISA 2009 podataka, Revija za socijalnu politiku, 25 (2): 133-156. https://doi.org/10.1146/10.3935/rsp.v25i2.1463

Raftery AE i Hout M (1993). Maximally maintained inequality: Expansion, reform, and opportunity in Irish education, 1921-75, Sociology of Education, 66 (1): 41-62. https:// doi.org/10.1146/10.2307/2112784

Reynolds AJ, Ou S-R i Topitzes JW (2004). Paths of effects of early childhood intervention on educational attainment and delinquency: A confirmatory analysis of the Chicago ChildParent Centers, Child development, 75 (5): 1299-1328. https://doi.org/10.1146/10.1111/ j.1467-8624.2004.00742.x

Scheiwe K i Willekens H (2009). Child Care and Preschool Development in Europe. London: Palgrave Macmillan.

Smith JR, Brooks-Gunn J i Kato Klebanov P (1997). The consequences of living in poverty for young children's cognitive and verbal ability and early school achievement. U: Duncan GJ i Brooks-Gunn J (ur.). Consequences of growing up poor. New York: Russell Sage, 132-189.

Stocké V (2007). Explaining educational decision and effects of families' social class position: An empirical test of the Breen-Goldthorpe model of educational attainment, European Sociological Review, 23 (4): 505-519. https://doi.org/10.1146/10.1093/esr/jcm014

Sylva K, Melhuish E, Sammons P, Siraj-Blatchford I i Taggart B (2004). The effective provision of pre-school education (EPPE) project: Findings from Pre-school to end of Key Stage 1. Nottingham: DCFS Publications.

Sylva K, Melhuish EC, Sammons P, Siraj-Blatchford I i Taggart B (2008). Final Report from the Primary phase: Pre-school, school and family influences on children's development during Key Stage 2 (7-11). Nottingham: DCSF Publications.

Sylva K, Melhuish E, Sammons P, Siraj-Blatchford I i Taggart B (2011). Pre-school quality and educational outcomes at age 11: Low quality has little benefit, Journal of Early Childhood Research, 9 (2): 109-124. https://doi.org/10.1146/10.1177/1476718X10387900

Van Belle J (2016). Early Childhood Education and Care (ECEC) and its long-term effects on educational and labour market outcomes. Santa Monica: RAND Corporation. https:// doi.org/10.1146/10.7249/RR1667

Šućur Zoran, Kletečki Radović M, Družić Ljubotina O i Babić Z (2015). Siromaštvo i dobrobit djece predškolske dobi u Republici Hrvatskoj. Zagreb: Ured UNICEF-a za Hrvatsku. 
Wardsworth MEJ (1986). Effects of parenting style and preschool experience on children's verbal attainment: Results of a British longitudinal study, Early Childhood Research Quarterly, 1 (3): 237-248.

Wu M (2005). The role of plausible values in large-scale surveys, Studies in Educational Evaluation, 31 (2-3): 114-128. https://doi.org/10.1016/j.stueduc.2005.05.005

\section{PRILOZI}

Tablica P1. Struktura obrazovanja roditelja: najviše postignuto obrazovanje roditelja (podaci za Hrvatsku)

\begin{tabular}{|c|c|c|c|c|c|}
\hline & PISA 2009 & PISA 2012 & PISA 2015 & TIMSS 2011 & TIMSS 2015 \\
\hline $\begin{array}{l}\text { oba roditelja bez srednje } \\
\text { škole }\end{array}$ & $7,0 \%$ & $5,7 \%$ & $3,6 \%$ & $6,5 \%$ & $3,2 \%$ \\
\hline trogodišnja srednja škola & $18,9 \%$ & $19,6 \%$ & $20,4 \%$ & \multirow[b]{2}{*}{$64,3 \%$} & $14,2 \%$ \\
\hline $\begin{array}{l}\text { četverogodišnja srednja } \\
\text { škola }\end{array}$ & $40,4 \%$ & $38,9 \%$ & $34,3 \%$ & & $44,2 \%$ \\
\hline stručni studij & $13,1 \%$ & $13,7 \%$ & $15,6 \%$ & $11,5 \%$ & $13,1 \%$ \\
\hline sveučilišni studij & $20,6 \%$ & $22,2 \%$ & $26,1 \%$ & $17,7 \%$ & $25,3 \%$ \\
\hline UKUPNO & $100,0 \%$ & $100,0 \%$ & $100,0 \%$ & $100,0 \%$ & $100,0 \%$ \\
\hline$N$ & 4889 & 4946 & 5716 & 4414 & 3869 \\
\hline
\end{tabular}

Tablica P2. Prosječna procjena razine matematičke, prirodoslovne i čitalačke pismenosti na TIMSS i PISA testovima s obzirom na najviše postignuto obrazovanje roditelja (podaci za Hrvatsku)

\begin{tabular}{|c|c|c|c|c|c|c|c|c|c|c|c|c|c|}
\hline & \multicolumn{3}{|c|}{ PISA 2009} & \multicolumn{3}{|c|}{ PISA 2012} & \multicolumn{3}{|c|}{ PISA 2015} & \multicolumn{2}{|c|}{ TIMSS 2011} & \multicolumn{2}{|c|}{ TIMSS 2015} \\
\hline & Mat & Čit & Pri & Mat & Čit & Pri & Mat & Čit & Pri & Mat & Pri & Mat & Pri \\
\hline $\begin{array}{l}\text { oba roditelja } \\
\text { bez srednje } \\
\text { škole }\end{array}$ & 400 & 414 & 428 & 413 & 433 & 441 & 412 & 433 & 422 & 449 & 478 & 434 & 470 \\
\hline $\begin{array}{l}\text { trogodišnja } \\
\text { srednja škola }\end{array}$ & 426 & 442 & 455 & 434 & 452 & 457 & 417 & 433 & 427 & \multirow{2}{*}{483} & \multirow{2}{*}{510} & 474 & 509 \\
\hline $\begin{array}{l}\text { četverogodišnja } \\
\text { srednja škola }\end{array}$ & 465 & 481 & 489 & 475 & 488 & 497 & 465 & 494 & 479 & & & 500 & 530 \\
\hline stručni studij & 474 & 493 & 503 & 476 & 487 & 496 & 476 & 498 & 488 & 505 & 531 & 514 & 543 \\
\hline sveučilišni studij & 491 & 508 & 519 & 509 & 520 & 523 & 499 & 521 & 508 & 527 & 549 & 537 & 565 \\
\hline
\end{tabular}




\title{
What's Kindergarten Got to Do with It? Access to Early Childhood Education and Care and Reproduction of Social Inequalities in Regular Education: Analysis of PISA and TIMSS Data
}

\author{
Teo MATKOVIĆ (it) \\ Zagreb, Croatia \\ teo.matkovic@gmail.com \\ Ivana DOBROTIĆ \\ Social Work Study Centre, Faculty of Law, University of Zagreb, Croatia \\ ivana.dobrotic@pravo.hr (corresponding author) \\ Jelena BARAN \\ Zagreb, Croatia \\ baranjelena@gmail.com
}

\section{ABSTRACT}

Numerous studies have pointed to the importance of early childhood education and care (ECEC) for the development of children's cognitive skills and their preparation for school, with the ECEC effect generally being stronger for the children coming from the families of lower socioeconomic status (SES). Empirical analyses of social inequalities in access to education and school achievement in Croatia have been primarily focussed on the later stages of schooling, while the ECEC area remains unexplored. The aim of this paper was to establish patterns of association between ECEC attendance and the cognitive achievements of children aged 10 and 15 in Croatia. More specifically, using the data collected for Croatia within the several waves of the PISA and TIMSS studies (2009-2015), we examined whether there was a link between ECEC attendance and subsequent level of cognitive skills in mathematics, reading and natural sciences (general positive contribution), and whether this effect differed with respect to parents' SES (compensatory effect). The analysis did not support the compensatory effect hypothesis, but in most cases a certain general contribution of long-term ECEC attendance to the cognitive achievements of pupils was found (ranging from one-fifth to one-tenth of the span of a single "level of proficiency" in TIMSS and PISA tests) which cannot be explained by parents' education or profession, migration background, household composition or local environment features. Observed within the context of the Croatian ECEC system and huge inequalities found in the frequency and duration of children's ECEC attendance in regards to parents' SES, the paper additionally points to the mechanism of effective maintenance of education inequalities in Croatia, which may be reduced by further expansion of the ECEC system.

Key words: early childhood education and care, PISA, TIMSS, reproduction of social inequalities, cognitive achievement 
